\title{
Vergilendirme ve Demokrasi Arasındaki İlişkinin Analizi: Manisa Celal Bayar Üniversitesi Örneği ${ }^{*}$
}

\section{Analysis of the Relationship Between Taxation and Democracy: The Case of Manisa Celal Bayar University}

\author{
Doç. Dr. Sibel AYBARÇiD), Prof. Dr. Sibel SELIM ${ }^{[12}{ }^{2}$, Nur Selin ARSLANiD3
}

\section{$\ddot{\mathbf{O z}}$}

Antik Yunan şehir devletlerine değin uzanan demokratik politik gelenek, 19. yüzyıl sonrasında normatif ve ampirik teorik tartı̧̧alara sahne olmuştur. Günümüzde demokrasi, farklı perspektiflerden tanımlanmaktadır. Zenginobuz vd. (2010, s. 2) tarafindan demokrasi, 'vergi veren, vergi verdiği için kamu erkini kullananlardan hesap sorma hakkı olan vatandaşların yönetimi' olarak tanımlanmaktadır. Vergi, bireylerin yönetime katılmalarını teşvik eden bir araç olarak algılanmaktadır. Bu noktada bir yandan vergilendirme düzeyindeki artışın sivil özgürlüklerin genişlemesini destekleyerek, demokrasi gelişimine katk1 sağlayıp sağlamayacağının; diğer yandan demokratikleşme düzeyindeki artışın vatandaşla devlet arasındaki uyumu olumlu etkileyerek, vergilendirme düzeyinin artmasına yol açıp açmayacağının tartışılması önem arz etmektedir. Bu çalışma, Manisa Celal Bayar Üniversitesi (MCBÜ) akademik personelinden oluşan gözlem kümesi kapsamında yapılan anket verileri kullanılarak, faktör analizi ve sıralı logit model uygulaması sonucu, vergilendirme ve demokrasi arasında ilişki olup olmadığını tespit etmeyi amaçlamaktadır. Çalışma sonucunda, vergilendirme ve demokrasi arasında bir ilişkinin olduğu tespit edilmiştir.

Anahtar Kelimeler: Vergileme, demokrasi, yükseköğretim, faktör analizi, sıralı logit model

Makale Türü: Araştırma

\begin{abstract}
The democratic political tradition, dating back to the ancient Greek city-states, has witnessed normative and empirical theoretical debates after 19th century. Today, democracy is defined from different perspectives. Zenginobuz et al. (2010, s. 2) define democracy as 'the management of citizens who have the right to call the public authority to account because of paying taxes'. Tax is perceived as a tool encouraging individuals to participate in governance. At this point, it's important to discuss on the one hand whether the raise in the level of taxation contributes to development of democracy by supporting the expansion of civil liberties, on the other hand whether the raise in the level of democratization leads to increase the level of taxation by positively affecting the harmony between the citizen and the state. The study aims to determine whether there is a relationship between taxation and democracy as a result of factor analysis and sequential logit model application by using the survey data made within the scope of the observation set consisting of academic staff of MCBU. As a result of this study, it has been determined that there is a relationship between taxation and democracy.
\end{abstract}

Keywords: Taxation, democracy, higher education, factor analysis, ordered logit model

Paper Type: Research

\footnotetext{
* Bu çalışma, MCBÜ Bilimsel Araştırma Projeleri Koordinasyon Birimi tarafindan desteklenmiştir, proje no: BAPK- 2018-173.

${ }^{1}$ Manisa Celal Bayar Üniversitesi, Ahmetli MYO, sibel.aybarc@cbu.edu.tr.

${ }^{2}$ Manisa Celal Bayar Üniversitesi, İktisadi ve İdari Bilimler Fakültesi, sibel.selim@cbu.edu.tr.

${ }^{3}$ Araştırmacı, Manisa, nur.selin.arslan326@gmail.com.
}

Atıf için (to cite): Aybarç, S., Selim, S. ve Arslan, N. S. (2019). Vergilendirme ve demokrasi arasındaki ilişkinin analizi: Manisa Celal Bayar Üniversitesi örneği. Afyon Kocatepe Üniversitesi Sosyal Bilimler Dergisi, 22(TBMM'nin 100. Yılı ve Millî İrade Özel Sayısı), 241-266. 


\section{Giriş}

Vergi, mali, ekonomik, sosyal ve siyasi boyutları olan çok yönlü bir kavramdır. Her ülkeye özgü ekonomik ve sosyal politikaların uygulama araçları arasında yer alan vergi sisteminin oluşturulması ve sürdürülebilirliği siyasi mekanizma eliyle gerçekleştirilmektedir. Özellikle seçim sürecinde siyasi mekanizmanın işlerliğinin sağlanması açısından rakip siyasi partilerin uyguladıkları/önerdikleri vergilendirme politikaları, belirleyici öneme sahiptir. Bu bağlamda, vergilendirme ve demokrasi arasında ilişkinin var olup/olmadığını tespit edebilmek için öncelikle kavramsal temelleri vurgulamak gerekmektedir.

Kamusal mal ve hizmetlerin hangi boyutta, ne kadar üretileceğine karar verme ve bu amaçla kamusal kaynakları kullanma tasarrufu, seçim mekanizmasıyla şekillenen kamusal tercih süreci ile belirlenmektedir. Kamu maliyesinin yapıtaşları olan kamu harcamaları ve kamu gelirlerine ilişkin kararlarda siyasi tercihlerin hâkim olması kamu maliyesi ile siyaset bilimi arasındaki ilişkiyi yadsınamaz kılmaktadır (Siverekli Demircan, 2004, s.594). Nitekim, vergi koyma yetkisinde halkın rızasının aranması, halk tarafından seçim ile oluşturulmuş meclis eliyle yerine getirilmektedir. Meclis, halkoyları sonucu politik karar alma yetkisiyle donatılmış siyasi partilerden oluşmaktadır. Bu açıdan değerlendirildiğinde, vergi, demokrasi, mükellef, seçmen ve siyasi parti ilişkilerinin birbiriyle doğrudan bağlantılı kavramlar olduğu görülmektedir (Öz ve Güler, 2015, s.35). Bu çalışma, akademisyenlerin vergi, demokrasi ve bu kavramlarla ilişkili yargılar hakkındaki algı ve tutumlarını tespit edip, vergi ve demokrasi arasında ilişki olup olmadığını açıklayarak literatüre katkı sağlamayı amaçlamaktadır.

\section{Genel Bilgiler: Vergi ve Demokrasi}

\subsection{Vergi Kavramı ve Gelişimi}

Türkçe kökenli kelime olan ve vermek kökünden türeyen "vergi" kelimesi, karş1lık beklemeden verilen hediye anlamına gelmektedir. Terminolojiye bakıldığında, devlet teşkilatının devam ettirilebilmesi için alınan para anlamına gelmektedir (Hançerlioğlu, 1999, s.468). Vergi, mali karakteristiğinin yanında tarihsel ve sosyal bir olgudur. İnsanlık tarihi boyunca yer ve zamana göre farklılık gösteren tarihsel ve sosyal olaylar, vergi kavramını da söz konusu farklılıklar doğrultusunda değişik anlamlara kavuşturmuştur (Edizdoğan, 2008, s.145).

Montesquieu, Locke, Hobbes, Von-Wieser gibi rasyonalist-ferdiyetçi devlet anlayışını benimseyen düşünürlere göre vergi, sunulan kamu hizmetlerinin adeta karş1lığ olarak özel kesimden kamu kesimine aktarılan "bedel" formunda iken; Mill, Pigou, Dalton gibi organikkollektivist devlet anlayışını benimseyen düşünürlere göre vergi, devletin kamusal hizmetlerini yerine getirilebilmesi için bireylerin (faydalanma derecesine bakılmaksızın) ödeme gücüne göre tek taraflı olarak saptadığı "zorunlu ödemeler" formundadır (Turhan, 1993, s.21; Muter, Çelebi ve Sakınç, 2008, s.120-133).

Antikçağdan günümüze değin farklı form ve anlamlara bürünen verginin genel kabul görmüş tanımı, "devletin ve kendisine vergilendirme yetkisi verilmiş diğer kamu kuruluşlarının yüklendikleri mali ve mali olmayan görevleri gerçekleştirmek üzere, gerçek veya tüzel kişilerden, yasal esaslara uymak kaydı ile hukuki cebir altında, karşılıksız olarak ve egemenlik gücüne dayanarak aldiğı para şeklindeki iktisadi değerler"dir (Muter vd., 2008, s.121).

İnsanlık tarihi boyunca farklı şekillerde ve farklı ad altında alınan vergi, başlangıçta gönüllülük esasıyla hediye, yardım şeklinde; ardından geleneksel yükümlülük ekseninde dini esaslara dayalı şekilde alınırken; günümüzde mükellefler tarafindan uyulması zorunlu kamusal ödev şeklinde alınmaktadır (Kayan, 2000, s.81).

En eski yazılı kanun metni olarak kabul edilen Urukagina Kanunu, ayrıca ölüm vergilerinin de yer aldığı ilk ve tek örnektir. Söz konusu kanun ile Kral Urukagina, halkı zor durumda bırakan ve yoksul kılan ağır vergilerin çoğunu kaldırmış ya da azaltmıştır (Canbay, 2009, s.11). İlkçağda dini bir vecibe olarak meşrulaştırılan ve düzenli alınmayan vergiler, Misır 
piramitleri inşasında halkın bedenen çalışmasından iltizam usulünü uygulayan Eski Roma'ya değin geniş coğrafyada uygulama imkânı bulmuştur (Kayan, 2000, s.81).

Otokratik ülke olan İngiltere'de baronların öncülüğünde ayaklanan Londra halkının kralın yetkilerini sınırlandırarak, demokrasi, parlamenter sistem ve insan hakları nosyonunun oluşumunu sağlayan 1215 tarihli Büyük Özgürlük Fermanı (Magna Carta Libertatum), günümüze değin uzanan "kanunsuz vergi olmaz" ilkesini gelenekselleștirerek, vergilemenin yasal altyapısına kaynak teşkil etmiştir (Canbay, 2009, s.40-41). İzleyen süreçte gerek Yüzyıl Savaşları nedeniyle vergilerin arttırılması, gerekse haksız vergi uygulamaları nedeniyle vergi isyanlarına sahne olan İngiltere'de, gerçek anlamda kralın vergileme yetkisini sınırlayan anayasal belgeler, 1628 tarihli Haklar Dilekçesi (Petition of Rights) ile 1689 tarihli Haklar Bildirgesi (Bill of Rights) olmuştur. İngiltere'nin kolonisi konumunda olan Amerika'da İngiltere tarafindan uygulanan ağır vergi politikası, bağımsızlık mücadelesi ile sonuçlanmış ve 1776 tarihli Amerikan Bağımsızlık Bildirgesi (American Declaration of Independence) ilan edilerek, "temsilsiz vergi olmaz ilkesi" benimsenmiştir. Avrupa coğrafyasında ise temel belirleyicileri arasında kralın vergilendirme yetkisini keyfi kullanımının engellenmesinin yer aldığı 1789 tarihli Fransız İhtilali ardından İnsan ve Vatandaş Hakları Bildirisi (Declaration des Droits de I'Homme et du Citoyen) ilan edilerek, (13.maddesindeki "vergide genellik ve eşitlik ilkesi" ile 14. maddesinde yer alan "vergilerin belirliliği ve kanuniliği ilkesi" kapsamında) kralın vergilendirme yetkisi sınırlandırılmıştır (Çağan, 1980, s.131).

Batının mali, ekonomik, sosyal, idari, hukuki ve demokratik alanlarda sağladığı gelişmelere ayak uydurmakta geç kalan (Tezcan, 2003, s.131) Osmanlı İmparatorluğu'nda, kuruluştan Tanzimat'a değin klasik mali yapı, dini esaslara göre alınan Şer'i Vergiler (zekat, öşür, haraç, cizye) ile geleneksel ve toplumsal esaslara göre alınan Örf'i Vergiler' ${ }^{4}$ (Tekalif-i Adiye, Tekalif-i Şakka) olmak üzere iki vergileme kaynağı üzerine şekillenmiştir. Osmanlı İmparatorluğu'nda günümüz anlamında vergileme ve hukuk devletine ilişkin ilk gelişme, 1808 tarihli Sened-i İttifak'tır. Padişah yetkilerini sınırlayan ilk anayasal belge olması ve iktidar kullanımına sadrazamın katılımını sağlaması açısından Sened-i İttifak, Osmanlı İmparatorluğu nezdinde Büyük Özgürlük Fermanı olarak algılanmıştır (Öz, 2004; Canbay, 2009, s.32-36).

Dünya ekonomisi, 20.yüzyıla derin izler bırakan savaşlara, krizlere ve küreselleşme süreciyle ekonomik, sosyal, siyasal ve teknolojik politikalarda değişim ve dönüşüme sahne olmuştur. Özellikle 20.yüzyılda yaşanan iki dünya savaşı ve ardından izlenen Keynesyen ekonomi politikaları ile ülkeler, müdahaleci maliye politikaları aracılığıyla makro ekonomiyi etkileme çabasına girmiş; vergi politikaları etkin bir enstrüman olarak kullanılmıştır. Şöyle ki gerek Keynesyen iktisat anlayışı gerekse vatandaşların büyük çoğunluğuna oy verme hakkı tanınması ile siyasal demokrasinin gelişmesi, vergileme anlayışını değiştirerek, progresif vergileme ve vergi adaletini ön plana çıkarmıştır. Gelinen süreçte vergi, gönüllülük esasının ötesinde sosyal, ekonomik ve siyasi amaçlara ulaşmada temel yapıtaşı formunu almıştır (Çevik, 2003, s.355-356).

Tarihsel gelişim sürecinde bir taraftan ulus devletlerde özellikle "temsilsiz vergileme"ye karşı halkın tepki ve isyan süreci sonucu ulaşılan demokratik yönetimlerde halkın seçim yoluyla vergi politikalarını etkileyebilmesi, diğer taraftan katılımcılık, yerinden yönetim gibi temel demokrasi enstrümanlarının uygulanma düzeyinin mükellefin/seçmenin vergi ödeme/ödememe kararı üzerinde etkili olabilmesi verginin siyasi fonksiyonunun önemini gözler önüne sermektedir (Aydoğan, 2017, s.20).

\footnotetext{
4 Örf'i vergiler arasında yer alan Baj (Bac), Ortadoğu'da hükümdarlara verilen para ve armağanları ifade etmektedir. Osmanlı İmparatorluğu'nda Bac, Osman Gazi tarafından pazara satılmak üzere getirilen her tür yük için 2 akçe alınmasını emretmesiyle uygulanmaya başlamıştır (Sirkeci ve Abdula, 2015, s.1248).
} 


\subsection{Demokrasi Kavramı ve Gelișimi}

Antik Yunan'da M.Ö. 5.yüzyılın ortalarında kullanılan ve "demos"(insanlar) ile "kratos"(güç) kelimelerinden türeyen "demokrasi" kelimesi, siyasi gücün tüm yetişkin nüfusun elinde olduğunu, benzer hiçbir grubun hükmetme hakkı olmadığını ifade etmek için kullanılmıştır (Sultana, 2012, s.27; Dahl, 2020). Başta Atina olmak üzere Yunan şehir devletlerinde "yurttaş" olan yetişkin erkeklerin yönetime doğrudan katılarak, kendi kendini yönetmelerini sağlayan doğrudan demokrasi müessesesi uygulama imkânı bulmuştur. Aristoteles Okulu tarafından tasnif edilen devlet şekilleri öğretisinde demokrasi, çoğunluğun egemen olduğu devlet şekli olarak tanımlanmıştır. Bunun yanı sıra demokrasi, kamusal faaliyetlerin çoğunluk ile iş birliği içinde düzenlenmesi, egemenlerin egemenlik altında bulunan çoğunluğa hesap vermesi, tüm yurttaşların aynı haklara sahip olması açısından diğer rejimlerden (azınlığa dayanan "aristokrasi ve oligarşi" ile tek kişi egemenliğine dayanan "monarşi ve tiranlık" yönetiminden) ayrılmıştır (Schmidt, 2001, s.13). Antik Yunan şehir devletlerinin M.Ö. 4.yüzyıl sonunda, Makedon egemenliği altında zorla biraraya getirilmesiyle bir taraftan devlet düzeni, diğer taraftan doğrudan demokrasi rejimi yıkılmış ve demokrasi söylem ve uygulamaları, 13.yüzyıla değin sessizliğe bürünmüştür (Uygun, 2017, s.113). İngiltere'de 1215 tarihli Büyük Özgürlük Fermanı, yalnızca vergi eşitliğini sağlama temelinde kalmamış, mutlak iktidarın yetkilerini de sınırlandırarak demokratikleşme sürecinin başlangıcı olmuştur. Demokrasinin ruhunda yer alan halk denetimi ile eşitlik olguları, aynı zamanda vergilendirme ilkelerini de oluşturmaktadır. Bu noktadan hareketle demokrasi ile vergileme ilkelerinin oluşumunun aynı döneme rastladığı söylenebilir (Şişman, 2009, s.31).

Demokrasi olgusu, 17.yüzyıl düşünürlerinden Montesquieu ile tekrar tartış1lmaya başlanmıştır. Montesquieu, demokrasinin siyasal değerlerin yanı sıra moral değerleri gerektiren bir rejim olduğunu ve gerçek gücünü erdemli rejim olmasından aldığını ifade etmiştir. Montesquieu'ya göre demokrasi, ancak iyi kurum ve yurttaşların varlığ 1 halinde iyi şekilde işlemektedir. Bu noktada egemenliğe sahip ulusun görev ve yükümlülüklerini "layıkıyla" yapmak, "layıkıyla yapamayacağg şeyleri ise temsilcilerine yaptırmak" suretiyle yurttaşlığın yüklediği sorumlulukları yerine getirip, siyasal erginliğe ulaşması gerekmektedir (Kavra, 1989, s.79). Bu noktadan hareketle, demokrasinin özünde yatan felsefenin siyasi kararlardan etkilenen insanların özellikle seçim süreci ile uygulanan politikalar ve tercihleri doğrultusunda söz hakkına sahip olduğu anlaş1lmaktadır (Frey, 2017, s.3).

Antik Yunan'dan Yeniçağ'a değin, uzak durulması gereken yönetim şekli olarak algılanan ve sessizliğe bürünen demokrasi söylemleri, Spinoza, Montesquieu ile farklı bakış açılarıyla tekrar gündeme gelmiş ve özellikle Rousseau ile asalet unvanı niteliği kazanmıştır. Rousseau, mutlak olma, bölünememe ve devredilememe özellikleri çerçevesinde demokrasi ve egemenlik olgularının ortak paydada değerlendirilmesi gerektiği fikrini ileri sürmüştür. Rousseau'ya göre, organik bütün olarak kabul edilen devlet iktidarı, halkın bizzat kendisi tarafından doğrudan doğruya kullanılan egemenliğe dayanmalıdır. Eğer egemenliğin temsilcilere bırakılması durumunda halkın, köleye dönüşeceğini belirtmiştir. Rousseau'nun kabul etmediği "temsil ilkesi", Sieyes tarafindan egemenlik olgusu ile özdeşleştirilerek, günümüz demokrasi felsefesinin özünü oluşturmuştur (Göztepe, 2010, s.133-134).

Antik demokrasi ile modern demokrasi arasında önemli nicel ve nitel farklılıklar bulunmaktadır. Özellikle modern çağda devlet anlayışı ve ölçeğinin değişimi, temsili demokrasiyi gerekli kılmış; ulus devlet felsefesi altında yurttaşın demokrasi sürecindeki rolünün değişimi, devlet-birey ayrılığını gündeme getirmiş ve süreç içerisinde yaşanan pek çok ekonomik, mali, siyasal, sosyal, dinsel etken demokrasi ilkelerini ve kurumları derinden etkilemiştir. 17.yüzyıldan günümüze demokratikleşme sürecinde yaşanan dönüm noktaları, aşağıdaki gibi özetlenmektedir (Uygun, 2017, s.114,117-118).

-Birinci Demokratikleşme Dalgası: Amerika'nın erkeklerin çoğuna oy kullanma hakkı tanıdığ 1820 'li y1llardan başlayan ve 1920'li yıllara değin uzanan süreçte, özellikle Avrupa ve İngilizce konuşulan ülkeler olmak üzere yaklaşık 30 ülke, demokrasi rejimini benimsemiştir. 
-ikinci Demokratikleşme Dalgası: II. Dünya Savaşı ardından otoriter ve totaliter rejimlerin yıkılıp, refah devleti anlayışı çerçevesinde demokrasi rejimini benimseyen ülke sayısında özellikle 1960'lı yıllarda artış görülmüştür.

- ̧̧̈̈üncü Demokratikleşme Dalgası: 1990'lı y1llarda otoriter sosyalist rejimlerin (özellikle Sovyet Sosyalist Cumhuriyetler Birliği, Yugoslavya, Çekoslovakya), kurucu ulusların bağımsızlık ilanlarıyla çözülmeye başlaması, soğuk savaş ve iki kutuplu dünya düzenini sona erdirmiş, serbest piyasa ekonomisi ve demokrasi anlayışının hızla yayılmasını sağlamıştır.

Tüm bu gelişmeler 1şı̆̆ında Dahl (2017), demokrasinin diğer rejimlerden çok daha iyi bir seçim olduğunu gösteren üstünlüklerini on maddeyle sıralamaktadır (Dahl, 2017, s.57-72):

-Demokrasi, diktatörlerin yönetimi ele almasını engellemekte ve zorbalığı önleyebilmektedir.

-Demokrasi, vatandaşlara demokratik olmayan sistemlerin sağlayamayacağ türde temel hakları (katılım hakkı, tartışma hakkı, oy verme hakkı gibi) sağlayabilmektedir.

-Demokrasi, vatandaşlara geniş kişisel özgürlük (ifade özgürlüğü, inanç özgürlüğü gibi) alanı sağlamaktadır.

-Demokrasi, vatandaşların temel hak ve menfaatlerinin korumasına yardımcı olmaktadır.

-Demokrasi, vatandaşların kendi seçimleri sonucu belirlenen kanunlar çerçevesinde yaşamalarına ve tasarrufta bulunmalarına firsat vermektedir.

-Demokrasi, vatandaşlara kendi seçimleri sonucu belirlenen kanunlar uyarınca yaşama fırsatı verdiği için yine kendi tercihlerine uygun davranması konusunda vatandaşların ahlaki sorumluluğunu yerine getirmesi için imkân sağlamaktadır.

-Demokrasi, insani gelişmişlik değerlerinin (sevgi, cesaret, adalet, dürüstlük, karar alıp uygulama gibi) gelişimine uygun zemin hazırlamaktadır.

-Demokrasi, vatandaşlar arasında mümkün olan en yüksek düzeyde siyasi eşitlik sağlamaktadır.

-Modern temsili demokrasiler, birbirleriyle çatışma sürecine girmezler.

-Demokrasi, uygulayıcı ülkeyi daha zengin kılmaktadır.

Garcia ve Haldenwang (2015), 131 ülkenin 1990-2008 arası döneme ilişkin siyasi rejimler ile verginin GSYH içindeki payını içeren verileri kullanarak gerçekleştirdikleri analiz sonucunda Tablo 1'deki yargılara ulaşmışlardır.

Demokratik rejimlerde vatandaşlar, vergilerin kaliteli kamu hizmeti ve yüksek refah düzeyi şeklinde karşılık bulduğu inancı ölçüsünde rejimi desteklemekte vergi ödemeyi haklı görmekte iken, otokratik rejimlerde yöneten kesimin çıkarları ve yöneten gruptan çıkar sağlama inancı ölçüsünde rejimi desteklemektedir (Garcia ve von Haldenwang, 2015, s.4-5). 
Tablo 1. Siyasi rejimler ve vergileme: Özet argümanlar

\begin{tabular}{|c|c|c|}
\hline Rejim Türleri & $\begin{array}{c}\text { Daha Yüksek Vergi Toplamaya Yol } \\
\text { Açan }\end{array}$ & $\begin{array}{c}\text { Daha Düşük Vergi Toplamaya } \\
\text { Yol Açan }\end{array}$ \\
\hline Demokrasi & $\begin{array}{l}\text {-Daha yüksek meşruiyet ve } \\
\text { güvenilirlik } \\
\text {-Daha iyi kamu hizmetleri, daha } \\
\text { yüksek yeniden dağıtım düzeyi } \\
\text {-Daha yüksek ekonomik büyüme ve } \\
\text { refah }\end{array}$ & $\begin{array}{l}\text {-Vatandaşların siyasi desteğine } \\
\text { daha bağlı ve bu nedenle daha } \\
\text { düşük bask1 uygulama tutumu }\end{array}$ \\
\hline Otokrasi & $\begin{array}{l}\text {-Uyumu dayatma konusunda daha } \\
\text { özgür } \\
\text {-Yönetenlerin kişisel çıkarlarına } \\
\text { yönelik gelir tahsisi } \\
\text {-Daha düşük resmi kalkınma desteği }\end{array}$ & $\begin{array}{l}\text {-Daha düşük meşruiyet ve } \\
\text { güvenilirlik } \\
\text {-Daha küçük ölçekli grup desteği, } \\
\text { vergi toplama ve dağıtımına } \\
\text { yönelik daha düşük ilgi }\end{array}$ \\
\hline
\end{tabular}

Kaynak: Garcia ve Haldenwang, 2015, s.16.

\subsection{Vergilendirme ve Demokrasi Arasındaki İlişkiyi Etkileyen Faktörler}

İnsanlık tarihi boyunca vergileme ve demokrasi, uygarlıklara, ideolojilere, pragmatik koşullara göre değişiklik göstermekle birlikte, özellikle toplum olma felsefesinin özünü oluşturan yurttaşlık bilincinin yapıtaşlarını oluşturmaktadır.

Özellikle son iki yüzyıl boyunca vergileme gerek seviye ve ölçek bakımından gerekse yapısal bakımdan değişim göstermiştir. Öyle ki, 19.yüzyıl başlarında gümrük vergilerinin ağırlıklı olduğu vergi yapısı, 20. yüzyılda yerini gelir vergisinin ağırlıklı olduğu bir yapıya bırakmıştır. Söz konusu değişim ve gelişmeyi açıklayan ortak akıl, yeniden dağıtım mekanizması ve hükümetin/iktidarın büyüklüğüne yol açan "demokrasi" olgusunun yaygınlaşması üzerine şekillenmektedir (Andersson, 2018, s. 111). Nitekim, olasılık oylama modeline göre demokrasilerde, uygulanacak kamu mali politikaları (özellikle vergilendirme ve kamu harcamaları) ile kişisel çıkarlarını hesaplayarak, hangi partiye oy vereceğine karar veren ideolojik olmayan (muhtemelen seçmenlerin büyük çoğunluğu) vatandaşların oyları etkilenmekte ve değiştirilebilmektedir (Profeta, Puglisi ve Scabrosetti, 2013, s.686). Bu noktada mükelleflerin sinıflandırılması da önem arz etmektedir (Karyağdı, 2015, s.121-123):

- Altın Mükellefler; toplumsal sorumluluk bilinci çerçevesinde vergi ahlakı yüksek ve kanunlara kendiliğinden uyum gösteren mükelleflerdir. Vergi sistemlerinin etkin çalıştı̆̆ 1 ve vergi suçlarına yönelik caydırıcılı̆̆ın yüksek düzeyde olduğu ülkelerde vergiye gönüllü uyum yüksek olmaktadır. Vergisel yaptırımların caydırıcı olmadığı durumda mükellef, rahatlıkla vergisel riskleri üstlenebilmektedir. Türkiye'de vergisel yaptırımların caydırıcı olmaması dolayısıyla altın mükellef grubuna giren mükelleflerin, gerçek anlamda vatandaşlık bilinci ve vergi ahlakıyla bu grupta yer aldıkları söylenebilir.

- Vergi Karşıtı Mükellefler; ödediği verginin karşılığının kamu hizmeti olarak kendisine geri dönmediği düşüncesiyle vergi ödememe davranışını haklı gören mükelleflerdir. Dünya genelinde söz konusu grubun vergi ödevini yerine getirmesi konusunda denetleyici ve ağır yaptırımlara tabi tutulması en etkin yöntem olarak kabul görmektedir.

- Kararsız Mükellefler; kamu otoritelerinin ekonomik ve siyasi politika uygulamalarında stratejik hedefleriyle yönlendirebilecekleri mükellef grubudur. Kamu otoritelerinin vatandaşlik bilincinin vergi bilinciyle özdeş olduğu, mükellef haklarına uygun idari işlemlerin yaygınlaştırılması, kapsamlı kontrol ve denetim faaliyetleri sonucu rüşvet ve yolsuzluğun olmadığının hissettirilmesi ile altın mükellef kademesine geçme olasılığı yüksek olan gruptur. Yüksek popülasyona sahip grubun vergi bilincinde meydana gelecek artış, demokratik hak ve özgürlüklerini kullanma kabiliyetini arttıracaktır. 
Vergileme ve demokrasi arasındaki (özellikle vatandaşların mükellef ve seçmen sıfatılla sahip oldukları önem ve belirleyiciliği esasına dayanan) ilişkiyi etkileyen çok sayıda faktör bulunmaktadır. Literatürde söz konusu faktörler yaş, cinsiyet, eğitim seviyesi, gelir düzeyi gibi demografik unsurlardan hesap verme, devlete bağlllık, siyasi tercihler, aidiyet duygusu, vergi yükü, vergi bilinci, vergi ahlakı, vergiye karşı tutum gibi mali, ekonomik ve politik unsurlara değin oldukça geniş yelpazede ele alınmaktadır.

Dünya Değerler Araştırması (The World Value Survey), dünya genelinde 90 ülkeyi kapsayan araştırma/anket verileri çerçevesinde vergiye karşı tutumu etkileyen faktörleri belirlemiştir. Analiz bulguları, özellikle 55 ülkenin cevapladığı "Eğer firsatınız olsa, vergi kaçırmayı haklı görür müsünüz?" ifadesini içeren anket sorusu üzerine şekillenmektedir. Ülkelerin belirli kısıtlar altında farklı kategorilere ayrılarak gerçekleştirildiği analiz, insanların vergiye karşı tutumunu açılamada kurumal ve sosyo-ekonomik faktörleri anlamanın önemini vurgulamaktadır (bkz. Grafik 1)(OECD, 2013, s.3):

- Ülkeleri için demokrasiyi en iyi yönetim rejimi olarak gören vatandaşlar, vergi kaçırmayı haklı görmemekte, vergi ödemeyi vatandaşlık ödevi şeklinde algılamaktadır.

- Mali yeniden dağıtımı demokrasinin temel özelliği olarak tanımlayan (hükümetin yoksulları sübvanse etmek için yüksek gelirlileri vergilendirmesi gerektiği kanısında olan) vatandaşlar, vergi ödemeyenlere nazaran daha yüksek düzeyde vergiye uyum göstermektedir.

- Devletine (kamu kurumlarıyla söz konusu kurumların şeffaflığına, etkinliğine) güvendiğini ifade eden bireyler, vergi ödemeyenlere nazaran daha yüksek düzeyde vergiye uyum göstermektedir.

- İnançları ve dini değerleri kuvvetli olanların vergi ödeme konusunda daha olumlu tutum sergiledikleri görülmektedir.

- Cinsiyet bazında, kadınların erkeklere nazaran daha yüksek düzeyde vergi bilinci ve uyumu sergilediği görülmektedir.

- Yaş almış insanlar, genç insanlara nazaran vergi kaçırma eylemini haklı görmemekte, vergi ödevlerine sadık davranmaktadır.

- Eğitim düzeyi arttıkça, vergi ödeme ve demokratik hakları kullanmaya yönelik tutum ve davranışların arttığı görülmektedir.

Grafik 1. Küresel düzeyde vergiye karşı tutumu etkileyen kurumsal ve sosyo-ekonomik faktörler

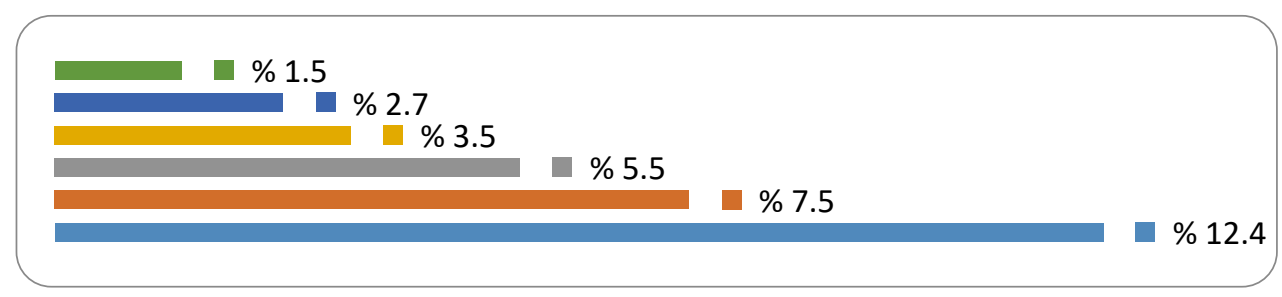

Kaynak: OECD (2013).

Gerçekten de ne kadar çok sayıda vergi mükellefi, topluma tanınan hakları kullanmak suretiyle politik karar alma sürecine katılabilirse, vergiye uyum düzeyi artarak o kadar çok sayıda vergi beyanı gerçekleşmektedir. Hatta vergi mükelleflerine (tanınan geniş hak ve yükümlülüklere sahip "vatandaş" sıfatıyla) referandum yoluna gitmek suretiyle, politikacıları daha iyi takip etme ve kontrol etme yetkisi de verilebilir. Günümüz temsili demokrasilerinde demokrasi enstrümanlarının etkin ve çeşitliliği, ödenecek vergilerin vatandaşların tercihleri ve ihtiyaçları doğrultusunda harcanmasına, bu durum da vatandaşların vergi ödeme konusunda motivasyonlarının artmasına yol açmaktadır. Nitekim burada kendisini demokratik kurallarla ön 
planda tutan hükümet, kendi gücüne sınırlamalar getirerek, vergi mükelleflerinin sorumlu kişiler olarak göründüğü algısı oluşturmakta ve mükellef tercihlerini siyasal süreçte dikkate almaktadır. Pratikteki uygulamaların yanı sıra demokratikleşme ile vergileme ve kamu harcamaları yapısı arasındaki bağlantı, ampirik bir tartışma olarak kalmaktadır (Torgler, 2003, s.5-6).

Devlete bağlılık ile bir çeşit vatandaşlık hakkının bedelini ifade eden vergiler, vergi bilinci ve ahlakı bulunmayan toplumlarda adeta zulüm olarak algılanmaktadır. Bu durumda tüm vatandaşlara devletin kendileri ötesinde bir varlık olmadığı ve vergi ödemenin "hukuki boyutları olan toplumsal ödev olduğu" anlayışının yerleştirilmesi gerekmektedir (Yeniçeri, 2005, s.280, 298). Böylece vergi bilincinin vatandaşlık bilinci çerçevesinde yerleşmesi sağlanmakta; halk, ekonomik ve siyasi aktiviteleri yüksek farkındalık derecesinde gerçekleştirmeye sevk edilmektedir.

Parlamenter demokrasilerde, seçim sonucu iktidara gelen siyasi parti/partiler, tüm yasal mevzuatın oluşturulması ve uygulanmasında olduğu gibi kamu maliyesi (kamu harcamalarının nasıl ve hangi boyutta gerçekleştirileceği, kamu gelirlerinin nasıl harcanacağı gibi) alanında da yetki sahibi olmaktadır. Bu bağlamda vatandaşlar, iktidarı elinde bulunduran siyasilerin politikalarını yakından takip ederek, olumlu/olumsuz tutum izlemekte (Çataloluk, 2008, s.219220) ve bunu ya vergi verme/vermeme şeklinde ya da izleyen seçim döneminde oy verme/vermeme şeklinde somutlaştırmaktadır.

Seçimler, demokratik hükümetlerin temel unsurudur. Vatandaşlar seçmen rolü ile bir aday1/partiyi/parti dışı adayı seçmek suretiyle kim tarafından hangi politika ile yönetileceğine yönelik tercihlerini belirlemektedirler. Çoğu kez halkın yönetime katılımı, hükümetin seçimi ile sınırlandırılmakta ve gelecek seçime kadar ertelenmektedir. Bu noktada seçmenler, kendilerini etkileyecek sosyo-ekonomik faktörleri (işsizlik, yoksulluk, idari yapı, hemşehrilik, ideoloji, etnik yapı, seçim kampanyaları, projeler gibi) göz önünde bulundurarak tercihlerini yapmaktadırlar (Özözen Kahraman, 2007, s.4-5,110-128).

Özetlemek gerekirse, geniş siyasi katılım ve sivil özgürlük temeline dayalı güçlü demokrasi, ödedikleri vergi vb. yükümlülüklerle kamu harcamalarını finanse eden vatandaşların kamu yönetimi aktörlerinden hesap sorabildiği ve bu hakkın kullanılması sonucu, kamu yönetiminde şeffaflık, etkinlik ve kalite anlayışı konusunda vatandaş nezdinde devlete olan güvenin artarak, vergi ödeme konusunda bilinçli olduğu bir sistemdir (Türedi ve Topal, 2016, s.80). Bu noktada demokrasinin sürdürülebilirliği, kamu yönetiminin şeffaf ve hesap verme sorumluluğu çerçevesinde ortak payda olan ulus bilinci ile politika belirlemesi ve faaliyete geçirmesine, vatandaşın ise mükellef/seçmen bilinci çerçevesinde vergi yükümlülüğünü ve oy kullanma hakkını layıkıyla yerine getirmesine bağlıdır.

\section{Yöntem}

$\mathrm{Bu}$ çalışmada yükseköğretim düzeyine sahip bireylerin vergi ve demokrasi algıları ile siyasal karar alma sürecinde ne derecede etkin olduklarına dair veriler, anket yönteminden yararlanarak toplanmıştır. Araştırmanın örneklemi olarak MCBÜ'de görevli akademisyenler belirlenmiş ve anket uygulanmıştır. MCBÜ Rektörlüğü Sosyal ve Beşeri Bilimler Bilimsel Araştırma ve Yayın Etik Kurulu tarafından 14.12.2018 tarih ve 2018/01 sayılı alınan karar gereği, etik yönden uygun bulunan anket, demografik bilgiler ile temel vergilemeye ilişkin bilgilerden oluşan 20 soruluk ilk kısım ile vergi ve demokrasi arasında ilişki olup olmadığına dair algıyı ölçmeye yönelik literatür araştırmasına (Çuhadar, 2006; Alkan, 2009; Yılmaz, 2015; Teyyare ve Kumbaşl1, 2016; Çiçek ve Bitlisli, 2017) dayalı olarak hazırlanıp, çeşitlendirilen ve 5'li Likert tipi ölçekli 35 soruluk son kısımdan oluşmaktadır. Çalışmada Sıralı logit model ile vergi ve demokrasi arasındaki ilişki ele alınmış ve faktör analizi sonucunda elde edilen beş faktör sıralı logit modele bağımsız değişken olarak dahil edilmiştir.

Ekonomi ve finans alanlarında ilk olarak 1975'te McKelvey ve Zavonia tarafindan kullanılan sıralı modeller, sıralı probit model ve sıralı logit model olmak üzere iki gruba 
ayrılmaktadır (Chow, 1988'den akt. Selim, 2012, s.60): Siralı Probit Model, normal olas1lik dağılımı üzerine odaklanmaktadır. Sıralı Logit Model, standardize edilen logistik olasılık dağılımına odaklanmakta; hataların logistik dağılımı bakımından sıralı probit modelden farklılaşmaktadır.

Sıralı logit modellerinde bağımlı değişken hem nitel hem de sıralı olmalıdır. "Sıralı olma"dan kasit, bir seçeneğin diğerine olan üstünlüğü değil, seçeneklerin birbirlerine eşit aralıklara/uzaklıklara sahip olmasıdır. Sıralı logit modellerde gizli değişken yaklaşımı çerçevesinde, gözlenen sıralı bağımlı $y$ değişkeni, gözlenemeyen $y^{*}$ değişkeninin bir fonksiyonudur. Gözlenemeyen $y^{*}$ değişkeni, açıklayıcı değişken ile hata terimi yardımıyla açıklanabilen sürekli ve farklı kesim noktalarına ( $\tau$ ile gösterilen eşik değerlere) sahip değişkendir.

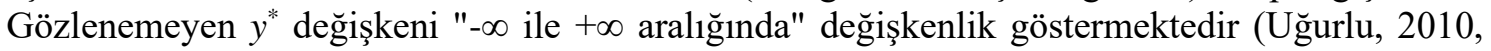
s.19).

İki değerli logit modelin genişletilmiş versiyonu olan sıralı logit model ile bu model çerçevesinde, gözlenen $(y)$ değişikeninin gözlenemeyen $\left(y^{*}\right)$ değişkenle ilişkilendirilmesini gösteren eşitlikler aşağıdaki formülüzasyonlarla ifade edilmektedir (Selim, 2012, s.60).

$$
y^{*}=\sum_{k=1}^{K} \beta_{k} x_{k}+\varepsilon
$$

$x_{i}$; bağımsız değişkenler vektörü,

$\varepsilon$; hata terimidir.

$y$ değişkeninin $m$ kategori gözlenmesi durumunda ise;

$$
\begin{aligned}
& y=m \text { eğer } \quad \tau_{m-1} \leq y^{*}<\tau_{m} \quad m=1 \ldots J \text { için } \\
& \tau \text {; eşik değer }
\end{aligned}
$$$$
y= \begin{cases}1 & \text { eger } \tau_{0}=-\infty \leq y_{i}^{*}<\tau_{1} \\ 2 & \text { eger } \tau_{1} \leq y^{*}<\tau_{2} \\ 3 & \text { eger } \tau_{2} \leq y^{*}<\tau_{3} \\ 4 & \text { eger } \tau_{3} \leq y^{*}<\tau_{4}\end{cases}
$$

Sıralı logit modelleri kapsamında bağımlı değişken kategori karşılaştırmaları bakımından farklı logit oluşturma modelleri bulunmaktadır. Bu noktada, "yığılımı olasılıklara dayanan sıralı logit modeller" uygulaması kolay ve yaygın olan model olarak kabul görmektedir. Söz konusu model bünyesinde "orantısal oran modeli", "orantısal olmayan oran modeli", "kısmi orantısal oran modeli" ile "kısıtlı ve kısıtsız orantısal oran modeli"ni barındırmaktadır (Ar1 ve Yıldız, 2016, s. $1365)$.

Açıklayıcı bir değişkenin her bir mevcut değerleri için gözlenen değişken y'nin seçilme olasılıkları hesaplanmaktadır. Olasılıklar, iki eşik değer arasındaki hataların dağıldığı alanı kapsamaktadır. Alanın hesaplanması, birikimli dağılım fonksiyonları arasındaki farkın tespitiyle mümkündür (Uğurlu, 2010, s.21). Siralı logit modelinde J tane kategori olmas1 durumunda, olasılıklara ait denklemler aşağıdaki gibi formülüze edilmektedir (Selim, 2012, s.60-61; Sarı ve Külekçi, 2017, s.322).

$$
\begin{aligned}
& \operatorname{Prob}(y=1)=L\left(-\sum_{k=1}^{K} x_{k} \beta_{k}\right) \\
& \operatorname{Prob}(y=2)=L\left(\tau_{2}-\sum_{k=1}^{K} x_{k} \beta_{k}\right)-L\left(-\sum_{k=1}^{K} x_{k} \beta_{k}\right),
\end{aligned}
$$




$$
\begin{aligned}
& \operatorname{Prob}(y=3)=L\left(\tau_{3}-\sum_{k=1}^{K} x_{k} \beta_{k}\right)-L\left(\tau_{2}-\sum_{k=1}^{K} x_{k} \beta_{k}\right), \\
& \operatorname{Prob}(y=J)=1-L\left(\tau_{J-1}-\sum_{k=1}^{K} x_{k} \beta_{k}\right) .
\end{aligned}
$$

Sıralı logit modelde elde edilen katsayılar, standartlaştırılmış katsayıları hesaplama yöntemi, tahmin edilen olasılıkları hesaplama yöntemi, tahmin edilen olasılıklardaki faktör değişmeyi hesaplama yöntemi, tahmin edilen olasılıklarda yüzde değişmeyi hesaplama yöntemi gibi farklı yöntemlerle yorumlanabilir (Emeç, 2002, s.17).

\section{Ampirik Analiz}

\section{1. Tanımlayıcı İstatistikler}

Bu çalışmada, MCBÜ'de görevli akademisyenlerden oluşan gözlem kümesi kapsamında vergi ve siyasal katılıma ilişkin algı ve beklenti düzeylerinin karşılaştırılması amaçlanmaktır. Örneklemin akademisyenlerden seçilmesinin sebebi yüksek gelir ve vergi bilinç düzeyine sahip olmalarıdır. Çalışmada ankete katılanların \%30.84'ü araştırma görevlisi, \%23.36'sı öğretim görevlisi, \%26.17'si doktor öğretim üyesi, \%10.28'i doçent, \%9.35'i profesörden oluşmaktadır. Değişkenlere ait tanımlayıcı istatistikler, Tablo 2 'de verilmiştir.

\begin{tabular}{|c|c|c|}
\hline Değişken & Ortalama & Standart Sapma \\
\hline Ödenen Aylık Vergi & 4.206 & 1.308 \\
\hline \multicolumn{3}{|l|}{ Cinsiyet } \\
\hline Erkek & 0.607 & 0.491 \\
\hline Kadin & 0.393 & 0.491 \\
\hline Yaş & 2.570 & 1.388 \\
\hline \multicolumn{3}{|l|}{ Eğitim } \\
\hline Lisans & 0.075 & 0.264 \\
\hline Yüksek Lisans & 0.290 & 0.456 \\
\hline Doktora & 0.636 & 0.484 \\
\hline \multicolumn{3}{|l|}{ Ünvan } \\
\hline Araş. Gör. & 0.308 & 0.464 \\
\hline Öğr. Gör. & 0.233 & 0.425 \\
\hline Dr. Öğretim Üyesi & 0.261 & 0.441 \\
\hline Doçent & 0.103 & 0.305 \\
\hline Profesör & 0.093 & 0.292 \\
\hline \multicolumn{3}{|l|}{ Görev yapılan birim } \\
\hline Fakülte & 0.271 & 0.447 \\
\hline Diğer & 0.729 & 0.447 \\
\hline Hizmet Süresi & 3.112 & 1.667 \\
\hline \multicolumn{3}{|l|}{ Gelir Grupları } \\
\hline $0-5.000 \mathrm{TL}$ arasi & 0.075 & 0.264 \\
\hline $5.001-5.000 \mathrm{TL}$ aras 1 & 0.626 & 0.486 \\
\hline 7.001-9.000 TL aras1 & 0.140 & 0.349 \\
\hline $9.001-11.000 \mathrm{TL}$ aras1 & 0.075 & 0.264 \\
\hline $11.001 \mathrm{TL}$ ve üzeri & 0.084 & 0.279 \\
\hline \multicolumn{3}{|l|}{ Faktörler } \\
\hline Faktör1 (Kamu Hizmeti & $-6.27 e-10$ & 1 \\
\hline \multicolumn{3}{|l|}{ Memnuniyeti) } \\
\hline Faktör2 (Vergi Bilinci ve & $-3.01 e-09$ & 1 \\
\hline \multicolumn{3}{|l|}{ Saydamlik) } \\
\hline Faktör3 (Vergi Politikası & $-9.67 e-10$ & 1 \\
\hline \multicolumn{3}{|l|}{ Memnuniyeti) } \\
\hline Faktör4 (Vergi Yükü) & $-7.14 \mathrm{e}-10$ & 1 \\
\hline Faktör5 (Vergi ve Demokrasi) & $1.01 \mathrm{e}-09$ & 1 \\
\hline Vergi yükü adil dağılımı & 0.374 & 0.486 \\
\hline Vergi ahlakı & 0.701 & 0.460 \\
\hline \multicolumn{3}{|c|}{ Vergisel Gelişmelerin Takip Türü } \\
\hline Resmi Gazete & 0.692 & 0.464 \\
\hline Basın yayın organları & 0.262 & 0.442 \\
\hline Vergi dairesi & 0.589 & 0.494 \\
\hline İş çevresi & 0.215 & 0.413 \\
\hline Muhasebeci / Mali müşavir & 0.131 & 0.339 \\
\hline
\end{tabular}

Tablo 2. Tanımlayıcı istatistikler 


\subsection{Değişkenlere Ait Frekans Tabloları ve Grafikler}

Çalışmada ankete katılanlara ait demografik bilgiler ile vergiye ilişkin bilgi ve algı soruları sıklık (frekans) analizine tabi tutulmuştur. Grafik 2, gözlem kümesinde ankete katılan akademisyenlerin "Tahmini ödediğiniz ortalama aylı vergi tutarl ne kadardır?" sorusuna verdikleri yanıtlara göre oluşturulmuştur. Ankete katılan "Dr. Öğretim Üyesi" unvanına sahip akademisyenlerin ödedikleri vergi tutarının en fazla olduğu söylenebilir.

Grafik 2. Akademisyen sayısına göre tahmini aylık ortalama ödenen vergi

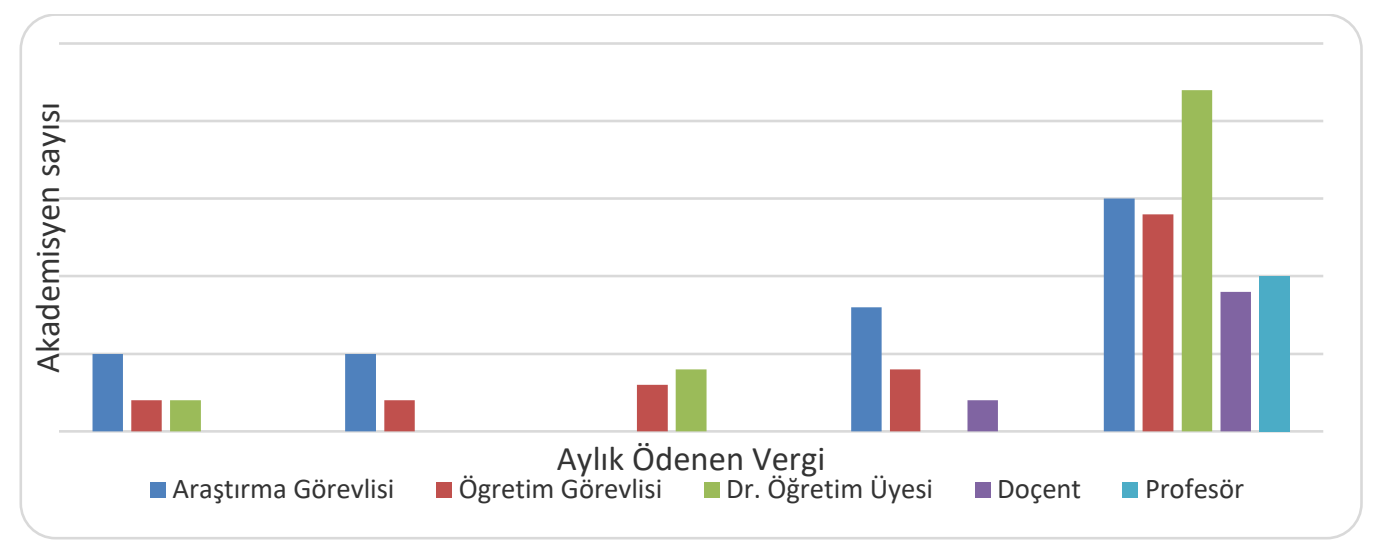

Grafik 3, ankete katılan akademisyenlerin "Elde ettiğiniz ortalama aylı geliriniz ne kadardır?" sorusu ile "Tahmini ödediğiniz ortalama ayllk vergi tutarı ne kadardır?" sorusuna verdikleri yanıtlara göre oluşturulmuştur. Ankete katılan ve "5.001-7000 TL." aras1 gelir elde eden akademisyenlerin "3.0001 TL ve üzeri" tutarda vergi ödedikleri yönünde vermiş oldukları yanıt ile toplam katılımcilar arasında \%39.25'lik oran ile en yüksek paya sahip oldukları söylenebilir (Tablo 3). Bu oran1 \%12.15'lik pay ile 7.001-9.000 TL aras1 gelir elde edip "3.0001 TL ve üzeri" tutarda vergi ödediklerini belirten ikinci grup izlemektedir.

Grafik 3. Akademisyen sayısına göre aylık ödenen verginin elde edilen gelir düzeyine göre dağ 11 เm

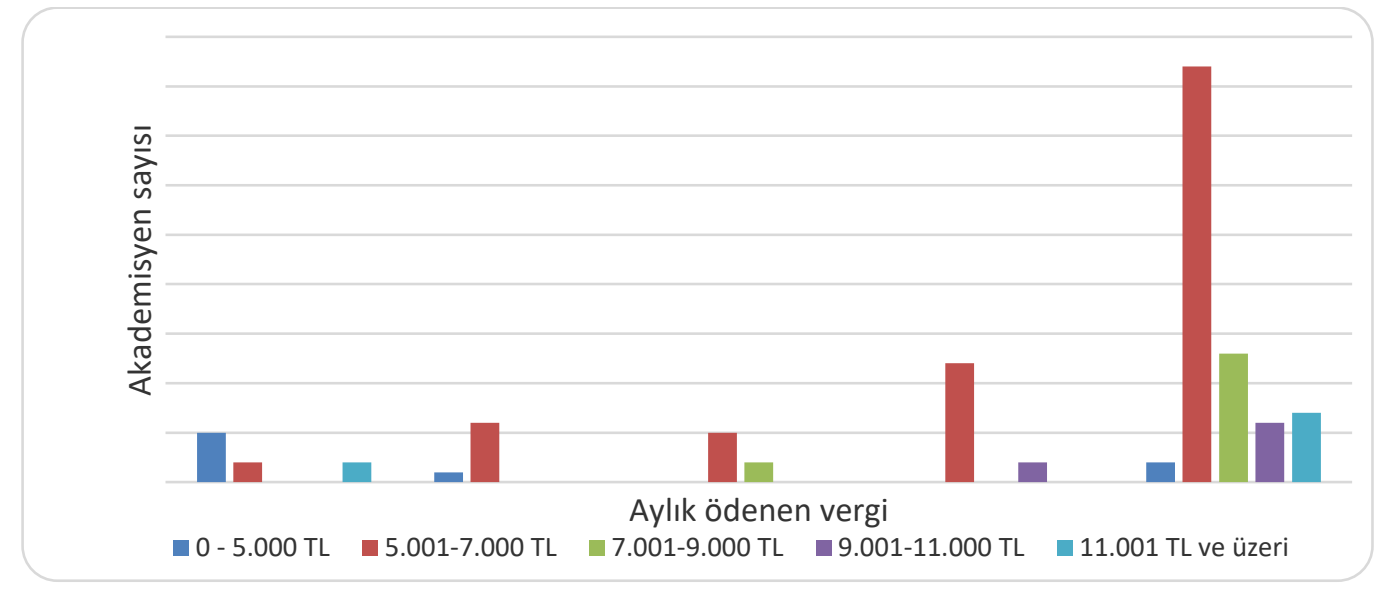


Tablo 3. Aylık ödenen vergi tutarının elde edilen gelir düzeyine göre dağılım oranı(\%)

\begin{tabular}{lccccc}
\hline \multicolumn{1}{c}{ Gelir } & \multicolumn{5}{c}{ Vergi Tutar1 } \\
\cline { 2 - 6 } & $0-500 \mathrm{TL}$ & $501-1000 \mathrm{TL}$ & $1001-2000 \mathrm{TL}$ & $2001-3000 \mathrm{TL}$ & $\begin{array}{c}\text { 3001 TL ve } \\
\text { üzeri }\end{array}$ \\
\hline $0-5.000 \mathrm{TL}$ & 4.67 & 0.93 & 0.00 & 0.00 & 1.87 \\
$5.001-7.000 \mathrm{TL}$ & 1.87 & 5.61 & 4.67 & 11.21 & 39.25 \\
$7.001-9.000 \mathrm{TL}$ & 0.00 & 0.00 & 1.87 & 0.00 & 12.15 \\
$9.001-11.000 \mathrm{TL}$ & 0.00 & 0.00 & 0.00 & 1.87 & 5.61 \\
$\begin{array}{l}11.001 \mathrm{TL} \text { ve } \\
\text { üzeri }\end{array}$ & 1.87 & 0.00 & 0.00 & 0.00 & 6.54 \\
\hline
\end{tabular}

Grafik 4, ankete katılan akademisyenlerden "Ödenen vergileri düşündüğ̈̈nüzde vergi ile ilgili ifadelerden hangileri sizin düşüncenize uygundur?" sorusuna tanımsal amaçlı anket kapsamında alternatif yargılardan kendi düşüncelerine en uygun olan üç seçeneği sırasıyla belirtmeleri istenmiştir. Ankete katılanların \%73.83'ü kendileri için "Vergi ödemek vatandaşlık görevidir." yargısının önemli olduğunu belirtmişlerdir. Seçilen bu yargının akademik unvana göre dağ 1 lımı incelendiğinde, \%30.38 oranda araştırma görevlisi, \%26.58 oranda öğretim görevlisi, $\% 22.78$ oranda doktor öğretim üyesi, \%7.59 oranda doçent, \%12.66 oranda profesör tarafindan vergi ödemek vatandaşlık görevi olarak algılanmaktadır.

Grafik 4. Akademik ünvana göre verginin vatandaşl1k görevi olarak algılanması

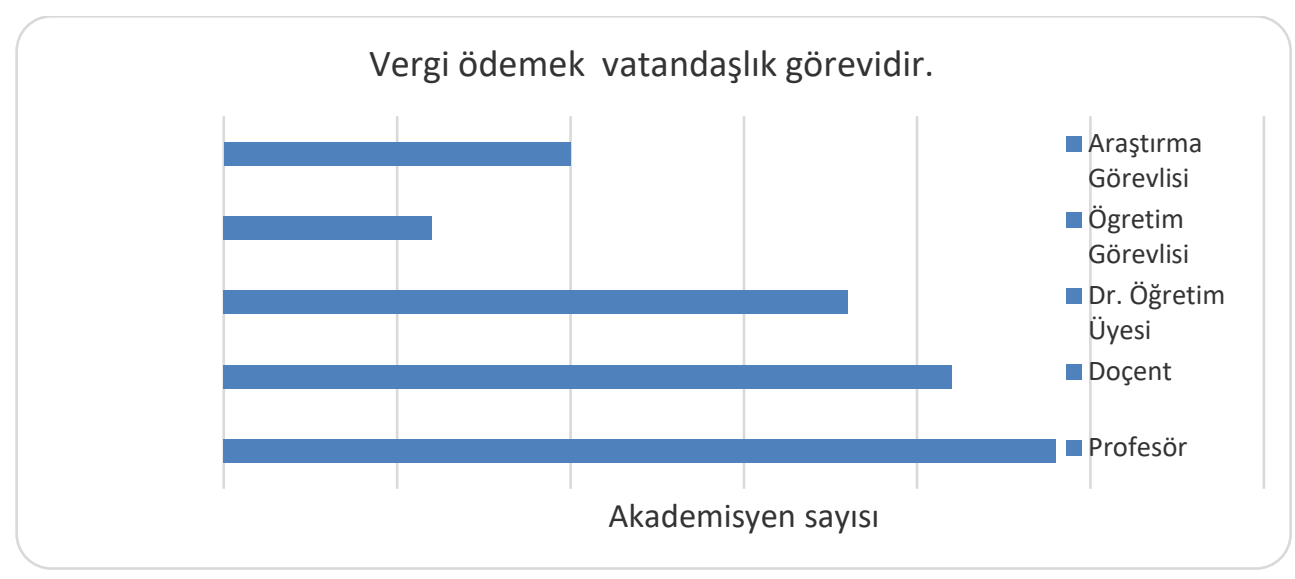

Vergi ödemenin vatandaşlık görevi olduğunu öncül düzeyde düşünen akademisyenlerin ankete katılan kendi unvanları içerisindeki payı incelendiğinde, \%72.73 oranla araştırma görevlileri, \%84 oranla öğretim görevlileri, \%64.29 oranla doktor öğretim üyesi, \%54.55 oranla doçent, \%100 oranla profesör olarak gerçekleştiği tespit edilmiştir. Söz konusu oran ile profesörlük unvanına sahip tüm bireylerde vergi bilincinin vatandaşlık görevi olarak yerleştiği ifade edilebilir. Buradan elde edilen sonuca göre, kişilerin vergiye karşı tutum ve davranışlarını önemli ölçüde etkileyen ve ödenen vergi miktarının farklılaşmasına sebep olan ekonomik, mali, sosyal, kültürel, kurumsal, siyasal ve yönetimsel vb. faktörler bulunduğu söylenebilir. Verginin konusu ve bireylerin ödeme güçleri; mükelleflerin 'vergi yükünü hissetme dereceleri; vergi baskısı, mükellefin adalet ve eşitlik algılaması; mükelleflerin verginin harcandığı yerler konusundaki algılama biçimi; kamu hizmetlerinden yararlanma düzeyi; mali rant ya da mali sömürü vb. faktörler vergi psikolojisi üzerinde etkili olmakta (Aktan ve Çoban, 2006, s.137138'den aktaran; Taşkın, 2020, s.72) ve vergi ödeme ya da vergi ödememe kararını etkilemektedir. 
Grafik 5. Akademik ünvana göre verginin kamu hizmeti karşı1lğı olarak algılanması

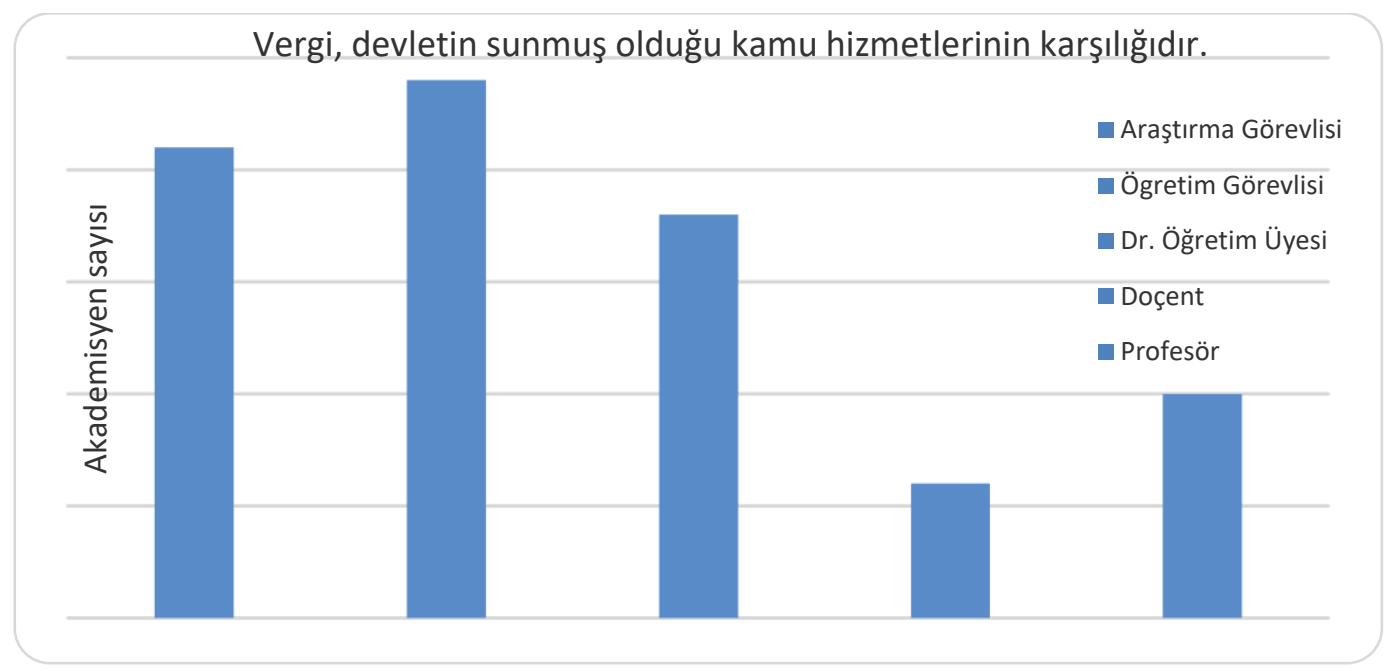

Grafik 5, ankete katılan akademisyenlerden "Ödenen vergileri düşündüğünüzde vergi ile ilgili ifadelerden hangileri sizin düşüncenize uygundur?" sorusuna tanımsal amaçlı anket kapsamında alternatif yargılardan kendi düşüncelerine en uygun olan üç seçeneği sirasıyla belirtmeleri istenmiştir. Ankete katılanların \%73.83'ü kendileri için "Vergi, devletin sunmuş olduğu kamu hizmetlerinin karşılığıdır." yargısının önemli olduğunu belirtmişlerdir. Seçilen bu yargının akademik unvana göre dağılımı incelendiğinde, \%26.58 oranda araştırma görevlisi, $\% 30.38$ oranda öğretim görevlisi, \%22.78 oranda doktor öğretim üyesi, \%7.59 oranda doçent, \%12.66 oranda profesör tarafından vergi kamu hizmetinin karşılığı olarak algılanmaktadır. Bilindiği üzere, verginin en temel karaktersitik özelliği, birebir karşılığının bulunmamasıdır. Ancak bunun dışında vergi, devletin sunduğu kamusal hizmetlerin temel finansman kaynağıdır.

Vergi ödemenin kamu hizmeti karşılığı olduğunu yine ilk üç önem düzeyinde düşünen akademisyenlerin ankete katılan kendi unvanları içerisindeki payı incelendiğinde, \%63.64 oranla araştırma görevlileri, \%96 oranla öğretim görevlileri, \%64.29 oranla doktor öğretim üyesi, \%54.55 oranla doçent, \%100 oranla profesör olarak gerçekleștiği tespit edilmiştir. Söz konusu oran ile profesörlük unvanına sahip tüm bireylerde vergi, kamu hizmetlerinin karşıllı̆ı olarak algilanmaktadır.

Grafik 6. Akademik Ünvana Göre Verginin Mali Yük Olarak Algılanması

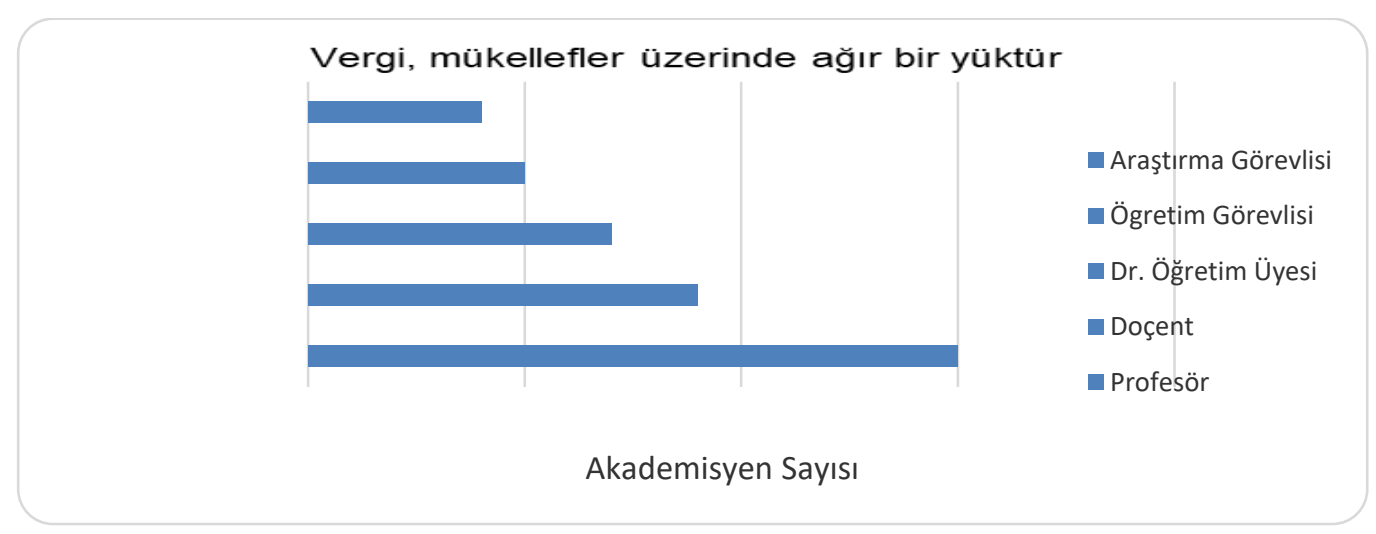

Grafik 6, ankete katılan akademisyenlerden "Ödenen vergileri düşündüğünüzde vergi ile ilgili ifadelerden hangileri sizin düşüncenize uygundur?" sorusuna tanımsal amaçlı anket kapsamında alternatif yargılardan kendi düşüncelerine en uygun olan üç seçeneği sırasıyla belirtmeleri istenmiştir. Ankete katılanların \%37.38'i kendileri için "Vergi, mükellefler üzerinde ă̆ır bir yüktür." yargısının önemli olduğunu belirtmişlerdir. Seçilen bu yargının akademik 
unvana göre dağılımı incelendiğinde, \%37.5 oranda araştırma görevlisi, \%22.5 oranda öğretim görevlisi, \%17.5 oranda doktor öğretim üyesi, \%12.5 oranda doçent, $\% 10$ oranda profesör tarafından vergi ağır mali yük olarak algılanmaktadır. Bilindiği üzere, mükellefin ödediği verginin elde ettiği gelir içindeki payı ne kadar artarsa, o kadar yük ve baskı hissi söz konusu olur. Anket bulguları çerçevesinde akademiyenlerin elde ettikleri gelir arttıkça, daha yüksek dilimde vergilendirilmekte, ancak elde edilen gelir düzeyi hissedilen vergi yükünü elimine etmektedir. $O$ nedenle daha düşük ücret geliri elde eden araştırma görevlileri, vergiyi ağır mali yük olarak algılarken, en yüksek düzeyde ücret geliri elde eden profesörler verginin ağır mali yükünü en düşük düzeyde algılamaktadır.

Grafik 7. Akademik ünvana göre vergi yükünün adil dağılımına yönelik alg1

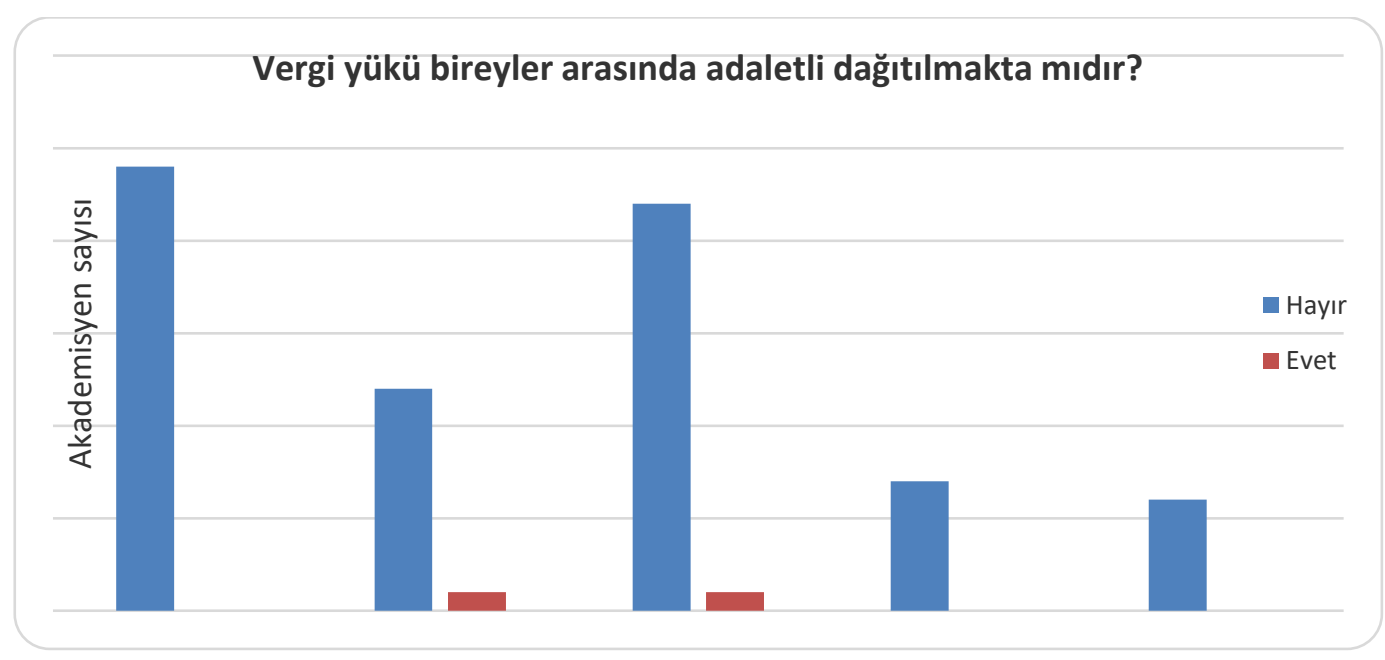

Grafik 7, ankete katılan akademisyenlere "Size göre vergi yükü bireyler arasinda adaletli dağıtılmakta mıdır?" sorusu yöneltilmiştir. Ankete katılanların \%66.36's1 vergi yükünün bireyler arasında adil dağıtılmadığını, \%1.87'si vergi yükünün adil dağıtıldığını belirtmiştir. Vergi yükünün adil dağıtılmadığını ifade eden katılımcıların akademik unvanlarına göre dağılımı incelendiğinde, \%22.43 oranda araştırma görevlisi, \%11.21 oranda öğretim görevlisi, \%20.56 oranda doktor öğretim üyesi, \%6.54 oranda doçent, \%5.61 oranda profesör olduğu görülmektedir.

Grafik 8. Akademik ünvana göre vergi ödemenin vatandaşa hesap sorma hakkı verdiğine dair alg1

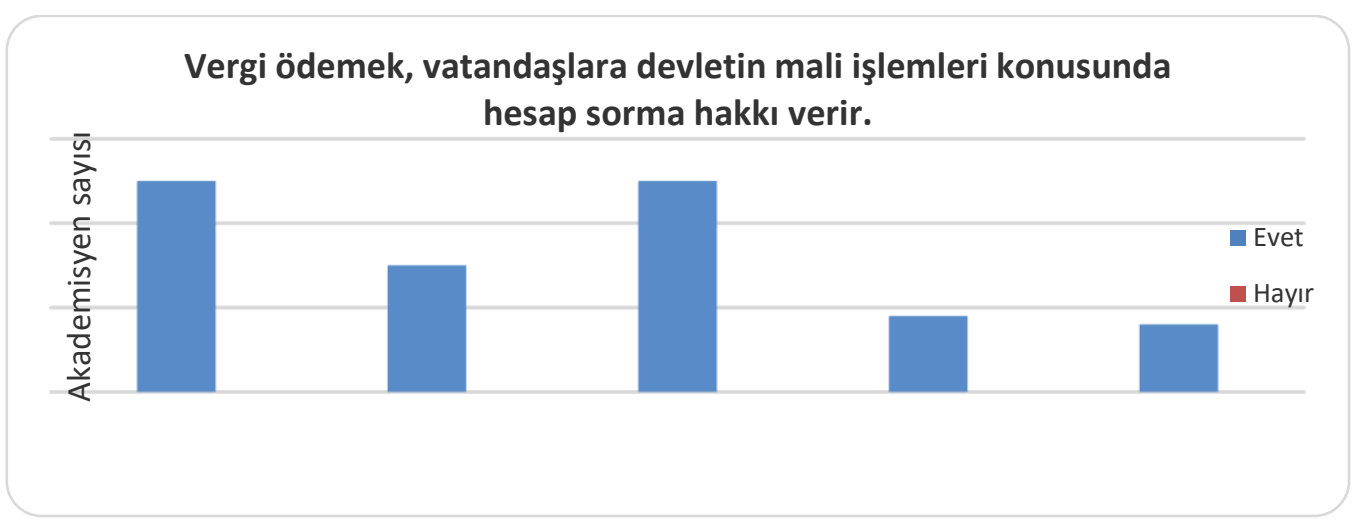

Grafik 8, ankete katılan akademisyenlere "Size göre vergi ödemek, vatandaşlara devletin mali işlemleri konusunda hesap sorma hakkı verir mi?" sorusu yöneltilmiştir. Ankete katılanların \%76.63'ü vergi ödemenin vatandaşlara devletin geçekleştirmiş olduğu mali işlemlerine dair hesap sorma hakkı vereceğini düşünmektedir. Vatandaş nezdinde verginin hesap sorma aracı olarak algılandığı yargısının akademik unvana göre dağılımı incelendiğinde, \%30.49 oranda araştırma 
görevlisi, \%18.29 oranda öğretim görevlisi, \%30.49 oranda doktor öğretim üyesi, \%10.98 oranda doçent, \%9.76 oranda profesör olduğu görülmektedir.

Grafik 9. Akademik ünvana göre vergi ödemenin ahlaklı olmanın bir göstergesi olduğuna dair alg1

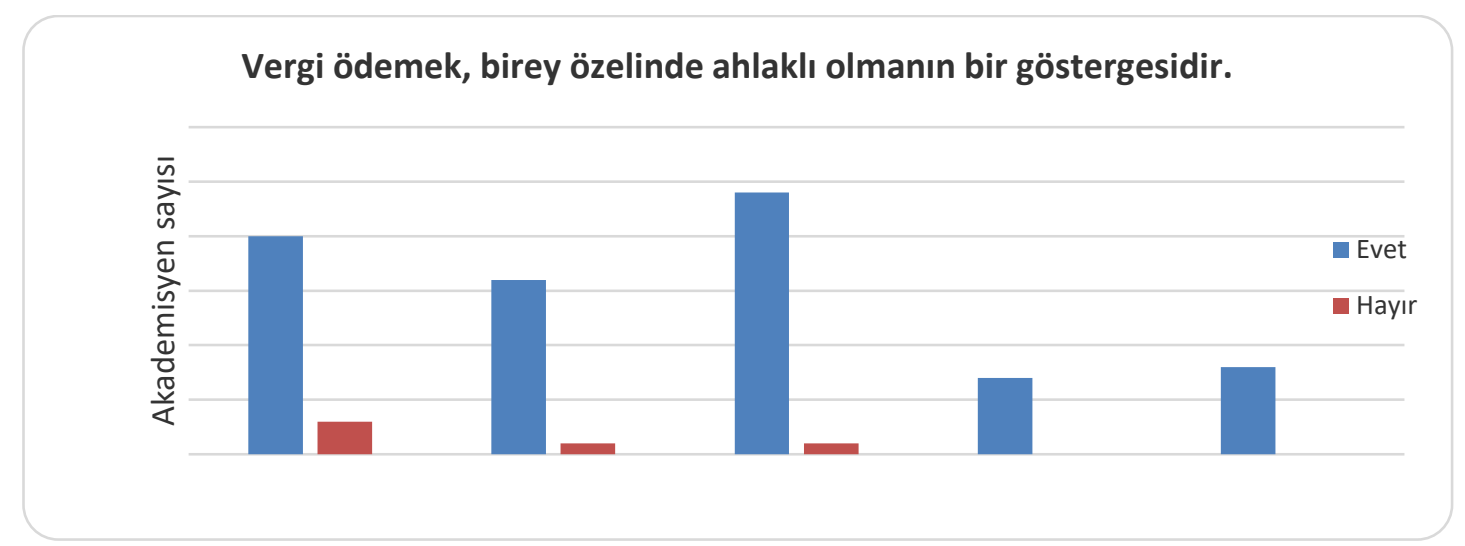

Grafik 9, ankete katılan akademisyenlere "Size göre vergi ödemek, birey özelinde ahlakll olmanın bir göstergesi olarak kabul edilir mi?" sorusu yöneltilmiştir. Ankete katılanların \%70.09'u vergi ödemeyi birey nezdinde ahlaklı olma ölçütü olarak algılamaktadır. Vatandaş nezdinde verginin ahlaklı olma göstergeleri arasında yer aldığına dair yargının akademik unvana göre dağılımı incelendiğinde, \%26.67 oranda araştırma görevlisi, \%21.33 oranda öğretim görevlisi, \%32 oranda doktor öğretim üyesi, \%9.33 oranda doçent, \%10.67 oranda profesör olduğu görülmektedir.

Grafik 10. Ödenen aylık vergi tutarına göre akademisyenlerin vergilendirme ve demokrasi arasında ilişki olduğuna dair algı

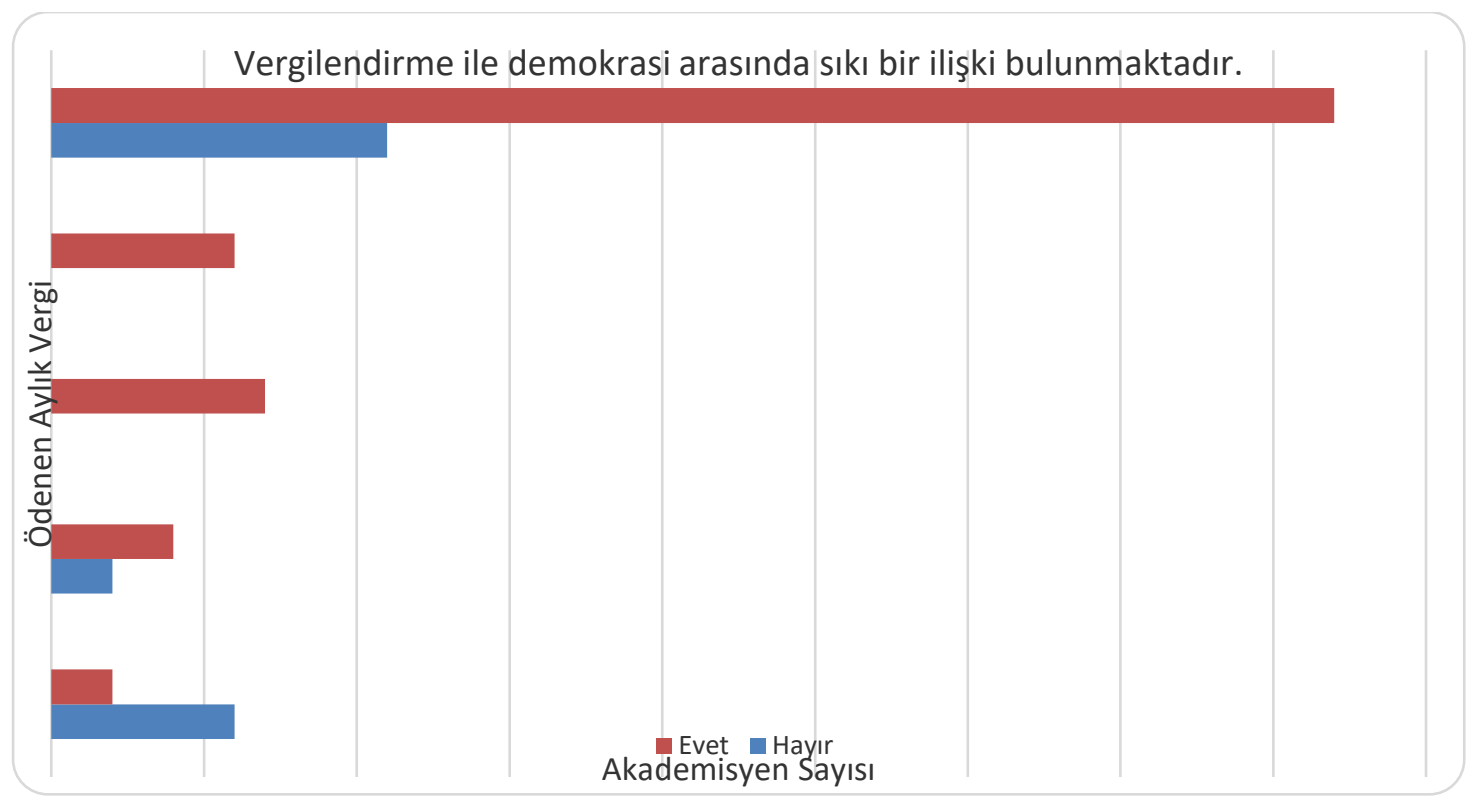

Grafik 10, ankete katılan akademisyenlerin "Vergilendirme ile demokrasi arasında sikı bir ilişki bulunmaktadır." ifadesine ilişkin yargıları tespit edilmek istenmiştir. Ankete katılanların \%57.01'i vergilendirme ile demokrasi arasında ilişki olduğunu; \%17.76'sı ilişki olmadığını ifade etmiş̧ir. Vergilendirme ile demokrasi arasında ilişki olduğu yargısına sahip akademisyenlerin, ödemiş oldukları aylık vergi oranı bazında dağılımı incelendiğinde, 0-500 TL arası vergi ödeyenler \%3.28'lik oranla en düşük, 3.001 TL ve üzeri vergi ödeyenler ise $\% 68.85$ 'lik oranla en 
yüksek sırada yer aldığı görülmektedir. Bu durumda daha yüksek düzeyde vergi ödeyenlerin vergilendirme ve demokrasi arasında ilişki olduğu düşüncesi ve bilinci ile hareket ettiği söylenebilir.

\subsection{Bulgular}

\subsubsection{Faktör Analizi Bulgulart}

$\mathrm{Bu}$ çalışmada kullanılan ölçekteki 26 maddeye ait faktör yapısını değerlendirmek amacıyla faktör analizi uygulanmıştır. Bulguların faktör analizine uygunluğunu tespit etmek için çeşitli analizler yapılmıştır. Analizler sonucu, Kaiser-Meyer-Olkin (KMO) ve Bartlett değerleri $(\mathrm{KMO}=0.714$, Bartlett Küresellik testi $=2,238 \mathrm{E} 3, \mathrm{p}=0.000)$ istatistiksel olarak anlaml bulunmuştur (Tablo 4). Bu durumda verilerin faktör analizine uygunluğu istatistiksel olarak tespit edilmiştir. Anket sonucu ulaşılan verilere Temel bileşen analizi yöntemi (Principal Component Analysis) ve Varimax dik döndürme tekniği (Varimax with Kaiser Normalization) uygulanmıştır.

Çalışmada, bir maddenin/yargının bir faktör altında yer alması için 0.50 ve daha büyük faktör yüküne sahip olması şartı aranmıştır. Bunun yanı sıra faktör analizinde öz-değeri 1'den büyük faktörler dikkate alınmıştır. Analiz sonucu, ölçekte belirtilen maddelerin/yargıların özdeğeri 1 'den büyük beş faktör altında toplandığ 1 tespit edilmiştir. Ölçekte yer alan tüm madde/yargı yüklerinin 0.50'tan büyük (0.525-0.866 arasında) olduğu görülmüştür. Toplam 26 maddeden/yargıdan oluşan ölçeğin açıkladığı toplam açıklanan varyans oranı \%67.795 olarak hesaplanmıştır (Tablo 5). Tablo 6'da faktör analizi sonucu bulunan faktörler ile faktörlerin sahip olduğu maddelerin/yargıların bulundukları faktördeki yük değerleri yer almaktadır. Elde edilen faktörler, sıralı logit modelde bağımsız değişken olarak kullanılmıştır.

Ölçeğin ve faktörlerin güvenirliğini test etmek üzere Cronbach's Alfa katsayısının değeri 0.909 bulunmuştur. Bu, ölçeğin yüksek güvenirliğe sahip olduğunu göstermektedir.

Tablo 4. KMO ve Bartlett Testi

\begin{tabular}{ccc}
\hline Kaiser-Meyer-Olkin (KMO) Örnek Yeterliliği Testi & 0.714 \\
\hline \multirow{3}{*}{ Bartlett Testi } & $\chi^{2}$ & $2.238 \mathrm{E} 3$ \\
& Serbestlik derecesi & 351 \\
& Olasılık & 0.000 \\
\hline
\end{tabular}

Tablo 6'da yer alan Rotasyonlu Faktör Matrisi'nin ilk sütununda ankette katılımcılara yöneltilen yargılar, diğer sütunlarda faktörler bulunmaktadır. Bulunan değerler ise faktör ağırlıklarıdır. Bu ağırlıklara göre elde edilen faktörler aşağıdaki şekilde adlandırılmıştır.

\footnotetext{
- Faktör1: "Kamu Hizmeti Memnuniyeti"

- Faktör2: "Vergi Bilinci ve Saydamlık"

- Faktör3: "Vergi Politikası Memnuniyeti"

- Faktör4: "Vergi Yükü"

- Faktör5: "Vergi ve Demokrasi"
} 
Tablo 5. Açıklanan toplam varyans

\begin{tabular}{crrrrrrrrr}
\hline \multirow{2}{*}{ Bileșen/Faktör } & \multicolumn{2}{c}{ Başlangıç Öz-Değerleri } & \multicolumn{3}{c}{ Faktör Yüklerinin Kareler Toplamı } & \multicolumn{2}{c}{$\begin{array}{c}\text { Döndürme Yapıldıktan Sonra Karesel } \\
\text { Yüklerin Toplamı }\end{array}$} \\
\cline { 2 - 10 } & Toplam Varyans\% & Birikimli\% & Toplam Varyans\% & Birikimli\% & Toplam Varyans\% & Birikimli\% \\
\hline 1 & 7.785 & 28.834 & 28.834 & 7.785 & 28.834 & 28.834 & 6.539 & 24.217 & 24.217 \\
2 & 5.667 & 20.990 & 49.825 & 5.667 & 20.990 & 49.825 & 4.246 & 15.725 & 39.942 \\
3 & 1.989 & 7.367 & 57.192 & 1.989 & 7.367 & 57.192 & 3.284 & 12.161 & 52.103 \\
4 & 1.559 & 5.773 & 62.965 & 1.559 & 5.773 & 62.965 & 2.378 & 8.809 & 60.912 \\
5 & 1.304 & 4.830 & 67.795 & 1.304 & 4.830 & 67.795 & 1.859 & 6.884 & $\mathbf{6 7 . 7 9 5}$ \\
\hline
\end{tabular}


Tablo 6. Rotasyonlu faktör matrisi

\begin{tabular}{|c|c|c|c|c|c|}
\hline & $\begin{array}{c}\text { Fakör 1 } \\
\text { Kamu Hizmeti } \\
\text { Memnuniyeti }\end{array}$ & $\begin{array}{c}\text { Faktör 2 } \\
\text { Vergi Bilinci } \\
\text { ve Saydamlık }\end{array}$ & $\begin{array}{c}\text { Faktör } 3 \\
\text { Vergi Politikası } \\
\text { Memnuniyeti }\end{array}$ & $\begin{array}{c}\text { Faktör } 4 \\
\text { Vergi Yükü }\end{array}$ & $\begin{array}{c}\text { Faktör 5 } \\
\text { Vergi } \\
\text { ve Demokrasi }\end{array}$ \\
\hline 1-Toplum geneli, sosyal güvenlik hizmetine yönelik eylem ve politika uygulamalarından memnundur.- & 0.866 & & & & \\
\hline 2-Toplum geneli, sağlık hizmetine yönelik eylem ve politika uygulamalarından memnundur. & 0.861 & & & & \\
\hline 3-Toplum geneli, istihdama yönelik eylem ve politika uygulamalarından memnundur. & 0.822 & & & & \\
\hline 4-Vatandaşlar, ödedikleri verginin karş̧ı̆ığını yeteri kadar almaktadır." & 0.811 & & & & \\
\hline 5-Toplum geneli, sunulan kamu hizmetlerinden memnundur. & 0.800 & & & & \\
\hline 6-Demokrasi sağlıklı işlemektedir. & 0.783 & & & & \\
\hline 7-Toplum geneli, eğitim hizmetine yönelik eylem ve politika uygulamalarından memnundur. & 0.776 & & & & \\
\hline 9-Toplanan vergiler harcanırken, şeffaf davranılmaktadır. & 0.696 & & & & \\
\hline 10-Kamu kaynaklarının ne şekilde kullanıldığı konusunda vatandaşlara hesap verilmektedir. & 0.679 & & & & \\
\hline $\begin{array}{l}\text { 11-Ödenen vergilerin hangi amaçla nerelere harcandığının açıklanması vatandaşların vergi bilincini } \\
\text { arttırmaktadır. }\end{array}$ & & 0.884 & & & \\
\hline $\begin{array}{l}\text { 12-Ödenen vergilerin hangi amaçla nerelere harcandığının açıklanması vatandaşların devlete olan bağlılığımı } \\
\text { arttırmaktadır. }\end{array}$ & & 0.838 & & & \\
\hline 13-Vergilerin alınması konusunda bilinç sahibiyim. & & 0.717 & & & \\
\hline 14-Vergi bilincinin artması, demokratik hakların farkındalığını artırmaktadır. & & 0.641 & & & \\
\hline 15-Vergi ödemek, vatandaşlara toplumu ilgilen diren konularda söz sahibi olma hakkı sağlamaktadır. & & 0.594 & & & \\
\hline 18-Vergi yaptırımları, siyasal katılımı etkilemektedir. & & & 0.672 & & \\
\hline 19-Toplum geneli, skk aralıklarla vergi affı uygulamasına gidilmesinden memnun değildir. & & & 0.668 & & \\
\hline 20-Vergi affı uygulaması, siyasal katılımı etkilemektedir. & & & 0.555 & & \\
\hline 21-Ödediğim vergiler dolayısıyla rahatsızlık duymaktayım. & & & & 0.821 & \\
\hline 22-Vergi öderken ekonomik açıdan zorlanmaktayım. & & & & 0.747 & \\
\hline 23-Vergi ödemek, vatandaşlara devletin mali işlemleri konusunda hesap sorma hakkı verir. & & 0.518 & & & \\
\hline 24-Oy kullanma hakkımı, devletin mali işlemlerine karşı ödül/ceza aracı olarak görmekteyim. & & & & & 0.583 \\
\hline $\begin{array}{l}\text { 25-Seçmen olarak vatandaşlar, ödedikleri verginin hangi amaçla nerelerde kullanıldığını oy san dığında } \\
\text { sorgulamaktadır. }\end{array}$ & & & & & 0.533 \\
\hline 26-Vergilendirme ile demokrasi arasında sıkı bir ilişski bulunmaktadır. & & & & & 0.525 \\
\hline
\end{tabular}




\subsubsection{Stralı Logit Model Tahmin Sonuçları}

$\mathrm{Bu}$ çalışmada vergi ve demokrasi arasındaki ilişkiyi tahminlemek için sıralı logit modelden faydalanılmıştır. Sıralı logit modelde paralel eğimler varsayımı, Brant (1990) tarafından önerilen test ile araştırılmışıı. Bu test sonucuna göre sıralı logit modelin kullanılmasının uygun olduğu bulunmuştur. Bu modelde bağımlı değişken bireylerin ödedikleri aylık vergi miktarı, bağımsız değişkenler ise cinsiyet, yaş, mezuniyet, unvan, görev birimi, hizmet yılı, elde edilen aylık gelir, vergi yükünün adil dağılımına ilişkin yargı, vergi ahlakı, faktör analizi sonucu elde edilen kamu hizmeti memnuniyeti, vergi bilinci ve saydamlık, vergi politikası memnuniyeti, vergi yükü, vergi ve demokrasi faktörleri ve vergisel gelişmelerin takip türüdür.

Siralı logit modelde tahmin edilen katsayılar doğrudan yorumlanamamaktadır. $\mathrm{Bu}$ nedenle katsayı yorumları yapılırken fark oranlarından faydalanılmaktadır. Tablo 7'deki fark oranları incelendiğinde erkekler kadınlara göre aylık 9.103 kat fazla vergi ödediklerini ifade etmişlerdir. Yaş kriteri açısından değerlendirildiğinde, 52 yaş ve üzeri akademisyenler 24-30 yaş arasındakilere göre 16.116 kat daha fazla vergi ödemektedir. Bu durumda, yaşın artması ile kişilerin gerek gelir düzeyi gerekse bilinç düzeyiyle olayları/olguları analiz kabiliyeti arttığı için daha yüksek vergi ödemeleri olağan görülmektedir. Akademisyenlerin eğitimleri dikkate alındığında mezun olunan eğitim seviyesi (lisans, yüksek lisans, doktora) arttıkça, aylık ödenen vergi miktarının da 1117.127 kat arttığı görülür. Gelir düzeyi ile ödedikleri aylık vergi arasındaki ilişki incelendiğinde, gelir düzeyi 7.001-9.000 TL arasında olanlar 7.000'den düşük gelir elde edenlere göre 54.472 kat daha fazla aylık vergi ödemektedir. Gelir Vergisi Kanunu 103.maddesinde yer alan artan oranlı vergi tarifesine göre, matrah arttıkça daha yüksek vergi dilimi üzerinden vergilendirme söz konusudur. 10.000 ve üzeri gelir grubunda yer alan akademisyenlerin daha yüksek gelir elde etmeleri dolayısıyla yüksek vergi dilimine geçip, yüksek oranda vergilendirilecekleri için diğer gruplara nazaran yüksek vergi ödemeleri söz konusu olacaktır.

Faktör bazında değerlendirildiğinde, kamu hizmeti ve memnuniyeti faktörünün (Faktör1) ve vergi yükünü (Faktör4) gösteren faktörün ödenen vergi miktarı üzerinde anlamlı etkisi bulunmamıştır. İkinci faktör olan vergi bilinci ve saydamlıktaki bir artış aylık ödenen vergi miktarını 17.261 kat arttırmaktadır. Bu durumda vatandaşlık bilinciyle vergiye yaklaşan mükellefin, ödenen vergilerin nereye, ne şekilde harcandığ sahip olduğunu hissetmesi, ödemiş olduğu vergi miktarını da arttırmaktadır. Vergi politikası memnuniyetindeki bir artış (Faktör3) aylık ödenen vergi miktarını 10.545 kat arttırmaktadır. Burada özellikle her bir oyun ne kadar önemli olduğu ve uygulanan vergi politikalarının siyasal katılımı ne denli etkilediği görülmektedir. Vergi ve demokrasi faktöründeki artışın (Faktör5) aylık ödenen vergi miktarını 0.010 kat kadar etkilediği görülmektedir. Bu durum mükelleflerin oy enstrümanını, devletin mali işlemlerine karşı bir tepki aracı olarak görmesini ifade etmektedir.

Vergi yükünün adil dağıldığını düşünen akademisyenler, vergi yükünün adil dağılmadığını düşünen ve kararsız olan gruba nazaran aylık 31.235 kat daha fazla vergi ödemektedir. Verginin ilgili kanunlara uygun ve zamanında ödenmesi konusunda mükellefin takındığı davranış, tutum ve inanç olarak ifade edilen vergi ahlakı, vergi ödemenin bir ahlak göstergesi olduğunu düşünenlerin aksi düşüncede olanlara nazaran 109.725 kat daha fazla aylık vergi ödedikleri tespit edilmiştir. Vergi ahlakı yüksek olan bireyler verginin ödenmemesinden rahatsızlık duyar ve vergi ödendiğinde ise haz duymaktadır. Vergi ahlakı düşük olan bireylerde ise vergi ödememek için yapılacak her türlü hile normal olarak kabul edilmektedir (Şenyüz, 1995, s.32'den aktaran Taşkın, 2010, s.73). Ayrıca tarafsızlık algısı, devlete olan güven, bireylerin sahip olduğu özellikler yanında ülkeler arasındaki farklılıklar da vergi ahlakını etkilemektedir (Alm ve Torgler, 2006, s.228-229'dan aktaran; Taşkın, 2010, s.73). Vergisel gelişmelerin takip türü değişkenleri dikkate alındığında ise akademisyenlerin en fazla resmi gazete yoluyla gelişmeleri takip ettikleri görülmektedir. Bunu sırasıyla iş çevresi ve basın yayın organları izlemektedir. 
Tablo 7. Siralı Logit Model tahminleri

\begin{tabular}{|c|c|c|c|c|c|}
\hline Değişken & Katsayı & Fark oranı & $\begin{array}{l}\text { Standart } \\
\text { hata } \\
\end{array}$ & $\mathrm{z}$ değeri & Olasilhk \\
\hline \multicolumn{6}{|l|}{ Cinsiyet } \\
\hline Erkek & 2.209 & 9.103 & 1.111 & 1.990 & $0.047^{* *}$ \\
\hline Yaş & 2.780 & 16.116 & 0.722 & 3.850 & $0.000^{*}$ \\
\hline \multicolumn{6}{|l|}{ Eğitim } \\
\hline Lisans Mezunu & 7.019 & 1117.127 & 2.357 & 2.980 & $0.003^{*}$ \\
\hline \multicolumn{6}{|l|}{ Ünvan } \\
\hline Profesör & 20.584 & $8.70 \mathrm{E}+08$ & 1130.386 & 0.02 & 0.985 \\
\hline \multicolumn{6}{|l|}{ Görev Yapılan Birim } \\
\hline Fakülte & -1.573 & 0.207 & 1.169 & -1.350 & 0.178 \\
\hline Hizmet Süresi & 1.014 & 2.755 & 0.770 & 1.320 & 0.188 \\
\hline \multicolumn{6}{|l|}{ Gelir Grupları } \\
\hline $7.001-9.000 \mathrm{TL}$ & 3.998 & 54.472 & 1.803 & 2.220 & $0.027 * *$ \\
\hline $9.001-10.000 \mathrm{TL}$ & -10.765 & 0.0001 & 2.848 & -3.780 & $0.000^{*}$ \\
\hline 10.001 TL ve üzeri & 11.202 & 73255.340 & 4.167 & 2.690 & $0.007^{*}$ \\
\hline \multicolumn{6}{|l|}{ Faktörler } \\
\hline $\begin{array}{l}\text { Faktör1 (Kamu Hizmeti } \\
\text { Memnuniyeti) }\end{array}$ & 0.130 & 1.139 & 0.367 & 0.350 & 0.723 \\
\hline $\begin{array}{l}\text { Faktör2 (Vergi Bilinci ve } \\
\text { Saydamlık) }\end{array}$ & 2.848 & 17.261 & 0.868 & 3.280 & $0.001^{*}$ \\
\hline $\begin{array}{l}\text { Faktör3 (Vergi Politikas1 } \\
\text { Memnuniyeti) }\end{array}$ & 2.356 & 10.545 & 0.576 & 4.090 & $0.000^{*}$ \\
\hline Faktör4 (Vergi Yükü) & 0.784 & 2.190 & 0.565 & 1.390 & 0.166 \\
\hline $\begin{array}{l}\text { Faktör5 (Vergi ve } \\
\text { Demokrasi) }\end{array}$ & -4.646 & 0.010 & 1.235 & -3.760 & $0.000^{*}$ \\
\hline Vergi yükü adil dağılımı & 3.442 & 31.235 & 1.476 & 2.330 & $0.020^{* *}$ \\
\hline Vergi Ahlak1 & 4.698 & 109.725 & 1.267 & 3.710 & $0.000^{*}$ \\
\hline \multicolumn{6}{|l|}{$\begin{array}{l}\text { Vergisel Gelişmelerin } \\
\text { Takip Türü }\end{array}$} \\
\hline Resmi Gazete & 7.805 & 2452.500 & 2.093 & 3.730 & $0.000^{*}$ \\
\hline Basın yayın organları & 2.499 & 12.176 & 1.317 & 1.900 & $0.058^{* * *}$ \\
\hline Vergi dairesi & 0.448 & 1.566 & 0.891 & 0.500 & 0.615 \\
\hline İş çevresi & 7.734 & 2285.806 & 2.034 & 3.800 & $0.000^{*}$ \\
\hline Muhasebeci / Mali müşavir & -7.469 & 0.001 & 1.987 & -3.760 & $0.000^{*}$ \\
\hline Log likelihood & -48.896571 & & & & \\
\hline Pseudo $\mathrm{R}^{2}$ & 0.5878 & & & & \\
\hline LR chi2(21) & 139.47 & & & & \\
\hline Barand test $\chi^{2}$ (Olasilık) & $4.56(0.252)$ & & & & \\
\hline
\end{tabular}

Not: $* \mathrm{p}<.01, * * \mathrm{p}<.05, * * * \mathrm{p}<.10$ olarak alınmıştır.

\section{Tartışma}

Magna Carta'dan günümüze kadar uzanan vergi ve demokrasi ilişkisi, politik düşünürlerden ekonomistlere değin farklı perspektifte ve çeşitli ampirik analizlerle inceleme alanı bulmuştur. Literatür incelendiğinde, değişen konjonktürel yapı gereği vergi ve demokrasi ilişkisinin güncelliğini ve önemini her daim koruduğu anlaşılmaktadır.

Feld ve Frey (2002) tarafindan 26 İsviçre kantonundaki vergi kurumlarına yöneltilen anket bulguları, vergi mükelleflerinin vergi kurumları tarafından gördükleri muamelelere tepkilerini, siyasi katılım haklarındaki farklılıklar ile açıklayabileceklerini göstermektedir (Feld ve Frey, 2002, s.87).

Ercins (2007), seçmenlerin yönlendirdiği seçim modeli esasına dayalı olarak Türk seçmen davranışı ve profilini ekonomik ve ekonomik olmayan değişkenlerle açıklamıştır. Seçilen modelde seçmen tercihlerini etkileyen değişkenler, parti kimliği, sosyal farklılıklar, değerler ve geçmiş politika uygulamaları çerçevesinde oy verme olarak belirlenmiştir. Seçmenin kendi 
ekonomik durumundan ziyade, ulusal ekonominin durumundan hareketle oy verdiği; oy verirken, gelecekten ziyade geçmişteki ekonomik durumu göz önünde bulundurduğu ifade edilmiştir. Seçmen davranışlarının şekillenmesinde makro göstergelerin (işsizlik oranı, enflasyon ve kişi başına düşen gelir miktarı gibi) önem arz ettiği belirtilmiştir (Ercins, 2007, s.26).

Zenginobuz vd. (2010) vergi odaklı çalışmalarında, Türkiye'de vergi bilinciyle söz konusu bilincin kamu yönetiminin daha demokratik olması yönünde sahip olduğu etkiyi tespit etmeyi amaçlamışlardır. Vergiyi ödeyen vatandaşlar kadar, vergilerle finanse edilen kamu hizmetlerinden yararlanan vatandaşların da dikkate alındığı çalışma bulguları kapsamında, vatandaşların hesap sorma hissiyatını karşılayacak şekilde bireysel ödedikleri vergileri takip etmelerini sağlayacak mekanizmaların oluşturulması öngörülmüştür (Zenginobuz vd., 2010, s.66).

Ziari ve Rahemi (2013), 21 ülkeyi yüksek, orta, düşük demokrasi indeksli olacak şekilde gruplandırıp, 2006-2011 y1llarına ait verilerle panel veri analizi uygulayarak vergi gelirleri ile demokrasi indeksi arasındaki ilişkiyi incelemişlerdir. Analiz bulgularına göre, yüksek ve orta düzeyli demokrasi indeksine sahip ülkelerde vergi gelirlerinin demokrasi indeksi üzerindeki etkisi pozitif; düşük düzeyli demokrasi indeksine sahip ülkelerde vergi gelirlerinin demokrasi üzerindeki etkisi negatiftir. Yüksek ve orta düzey demokrasi indeksine sahip ülkelerde vatandaşlar, vergi ödüyorlarsa, siyasi katılım haklarını sıkı biçimde kullanmakta ve iktidarı etkileme gücüne sahip olabilmektedir (Ziari ve Rahemi, 2013, s.17).

Baskaran ve Bigsten (2013), 1990-2005 arası dönemde 31 Sahra-Altı Afrika ülkesini kapsayan veri seti kullanarak, mali kapasitenin (ülkedeki vergilenebilir gelir düzeyi/potansiyeli) Sahra-Altı Afrika'da hükümet kalitesini (yolsuzluk, hesapverme, etkin kamu yönetimi kriterleri çerçevesinde) olumlu etkileyip etkilemediğini incelemişlerdir. Bulgular, Sahra-Altı Afrika'da mali kapasite arttıkça, yolsuzluğun azaldığına ve demokratik uygulamaların arttı̆̆ına dair tutarlı kanitlar sunmaktadır (Baskaran ve Bigsten, 2013, s.92).

Demir (2013), Türkiye'yi kapsayan analizinde, yedi coğrafi bölgeden birer tane olmak üzere 7 büyükşehir belediyesinde 1250 vergi mükellefine yönelttiği anket sorularıyla diğer değişkenlerin sabit olduğu varsayımı altında (ceteris-paribus), vatandaşın mükellef olarak maruz kaldığı vergi yükünün, seçmen olarak yapacağı tercihlerin belirlenmesinde ne ölçüde etkili olduğunu araştırmıştır. Bulgulara göre, vergi mükelleflerinin \%32.5'i vergi yükünü azaltacak siyasi partilere oy vereceğini belirtmiştir. Analiz kapsamında gelir düzeyi, vergi baskısı, genel ekonomik durum, kamu hizmetlerinden memnuniyet, yolsuzluk, vergi kaçırma eğilimi, devlete güven ve bağl1lık düzeyi, vergi cezaları ile vergi ahlakı gibi faktörlerin de olumlu ya da olumsuz şekilde seçmen tercihleri üzerinde etkili olduğuna dair yargılara ulaşılmıştır (Demir, 2013, s.39, $43,53)$.

Prichard vd. (2014), Uluslararası Vergi ve Kalkınma Merkezi aracılığıyla 1990-2010 aras1 dönemde 188 ülkeye ait verilerin bulunduğu Kamu Gelirleri Veriseti'nden yararlanarak gerçekleştirdikleri analiz sonucu, vergi bağlılığ ile demokrasi arasında olumlu ilişki; vergi dış1 gelir ile demokrasi arasında ise olumsuz ilişki tespit etmişlerdir (Prichard vd., 2014, s.42).

Yılmaz (2015), Zonguldak, Bartın ve Karabük illerinde faaliyet gösteren beyan esasına tabi 273 mükellef ile tevkifata tabi 347 mükellef arasında vergi ödeme şekli bakımından vergi yükünün daha yoğun hissedilmesi ve buna bağlı olarak vergi ve vatandaşlık bilincinin nasıl şekilleneceğini, yüz yüze anket yöntemiyle araştırmıştır. Bulgulara göre, "vergi ve hizmet sunumu", "vergi ve saydamlık", "vergi ve demokrasi", "vergi ve yönetim" faktörleri çerçevesinde, beyan yoluyla vergilendirilen mükelleflerin en yüksek alg1 düzeyleri "vergi ve hizmet sunumu" faktöründe; tevkifata tabi mükelleflerin en yüksek algı düzeyleri "vergi ve demokrasi" faktöründe gerçekleşmektedir. Analizin önemli bulgusu, bireylerin vatandaşlık ve vergi bilinci çerçevesinde seçmen/mükellef olarak gerçekleştirdikleri tutum ve davranışlar, kamu yönetimini daha saydam 
ve hesap verebilir kılmakta, doğal olarak bu süreç demokrasinin sürdürülebilirliğini arttırmaktadır (Y1lmaz, 2015, s.204, 210).

Öz ve Güler (2015), Türk siyasi tarihinde faaliyet gösteren parti programlarındaki vergi uygulamalarını ve bu uygulamaların mükelleflerin seçmen olarak davranışlarını nasıl etkilediğini tespit etmişlerdir. Özellikle 2015 'te aktif olan bazı parti programlarındaki vergi politikaları üzerine yoğunlaşan çalışmada, "vergilendirme ile siyasi parti" ilişkisinin, "seçmen olan mükellef ile politika uygulayacak olan seçilenler" arası ilişkiye benzerliğinden hareketle demokrasi ile vergi arasında ilişki kurulmaktadır. Söz konusu ilişkide seçmen, oy vererek bir taraftan yönetime katılma isteğini belli etmekte, diğer taraftan seçtiği siyasi partinin politika ve programına güvenini ifade etmektedir. Burada seçmenin oylama tercihi, siyasi parti programlarında özellikle vergiye dair vaat ve politikaların kişisel çıkarları ile örtüşmesine göre şekillendiği ifade edilmiştir (Öz ve Güler, 2015, s.35, 38, 61).

Türedi ve Topal (2015), 60 ülkenin 2006-2012 arası döneme ait verilerinden yararlanarak, gelişmekte olan ülkelerde vergilendirme ve demokrasi arasındaki ilişkiyi inceledikleri çalışmada, çift yönlü nedensellik ilişkisi tespit etmişlerdir. Analiz bulgularına göre, gözlem kümesindeki gelişmekte olan ülkelerde bir taraftan vergi artışları, (özellikle hukuk üstünlügü, ifade ve inanç özgürlügü gibi) sivil özgürlüklerin yaygınlaşmasını sağlayarak, demokrasinin gelişmesini desteklerken, diğer taraftan demokrasinin gelişimi (demokratik hak ve özgürlükler, siyasal katılım) vatandaş-devlet bağlılığı ve uyumunu arttırarak, vergi bilinci dolayısıyla vergilendirme düzeyini de arttırmaktadır (Türedi ve Topal, 2015, s.63).

Vergilendirme ile demokrasi arasında ilişki olduğunu düşünen araştırmaların aksine, herhangi bir ilişkinin olmadığını ileri süren çalışmalar da bulunmaktadır.

Cheibub (1998), demokrasi ve otokrasi rejimlerinin vergilendirme üzerindeki etkisini ölçmek amacıyla 1970-1990 arası dönemde 108 ülkeye ait verilerle panel regresyon analizi gerçekleştirmiştir. Analiz bulguları çerçevesinde, demokrasilerin otokrasilerden daha az vergi geliri sağlama kapasitesine sahip olduğu yönünde herhangi bir kanıt bulunamamıştır (Cheibub, 1998, s.351, 373).

Sağbaş ve Saruç (2003), Türkiye'de 3.11.2002 tarihli genel seçim ardından uygulanan 411 anket çerçevesinde, seçmenlerin oy kullanırken, siyasi partilerin vergi vaatleri ve politikalarından etkilenip, etkilenmediklerini incelemişlerdir. Test ettikleri "seçmenin parti tercihinde partilerin vergi konusundaki politikalarının etkisi yoktur." hipotezini doğrulayan bulgulara ulaşılmıştır (Sağbaş ve Saruç, 2003, s.130, 141).

Literatürde vergilendirme ve demokrasi arasında mevcut tartışmalar incelenerek, gerçekleştirilen bu çalışma sonucunda, vergilendirme ve demokrasi arasında ilişki olduğu tespit edilmiştir.

\section{Sonuç ve Öneriler}

Bu çalışmada amaç, MCBÜ akademisyenlerinden oluşan gözlem kümesi kapsamında yapılan anket verileri kullanılarak faktör analizi ve sıralı logit model ile vergilendirme ve demokrasi arasında ilişki olup olmadığını araştırmaktır. Örneklemin akademisyenlerden seçilmesinin sebebi yüksek gelir ve vergi bilinç düzeyine sahip olmalarıdır. Elde edilen bulgulara göre erkekler kadınlara göre daha fazla vergi ödemektedir. Akademisyenlerin yaşı dikkate alındığında 52 yaş ve üzeri akademisyenlerin 24-30 yaş arasındakilere göre daha fazla vergi ödedikleri görülmektedir. Buna göre yaş ile birlikte kişilerin vergi konusundaki bilinç düzeyi de atmaktadır. Akademisyenlerin eğitimleri dikkate alındığında eğitim seviyesi (lisans, yüksek lisans, doktora) arttıkça, aylık ödenen vergi miktarı da artmaktadır. Gelir düzeyi ile ödedikleri aylık vergi arasındaki ilişki incelendiğinde, 10.000 ve üzeri gelir grubunda yer alan akademisyenler daha yüksek gelir elde ettiklerinden dolayı yüksek vergi diliminde yer almaktadırlar. Bundan dolayı diğer gruplara nazaran yüksek vergi ödemeleri söz konusu olmaktadir. 
Faktör analizi aracılığıyla oluşturulan faktörlerden, kamu hizmeti ve memnuniyeti ve vergi yükünü gösteren faktörlerin ödenen vergi miktarı üzerinde anlamlı etkisi bulunmamıştır. Çalışmada vergi bilinci ve saydamlık ve vergi politikası memnuniyetindeki artışın aylık ödenen vergi miktarını arttırdığı görülmektedir. Ayrıca vergi ahlakına sahip olan akademisyenlerin ödedikleri vergi tutarının da arttığı sonucuna ulaşılmıştır. Vergi ahlakı ve güven, devlet ile vatandaş arasındaki ilişkinin yapıtaşını oluşturmaktadır. Nitekim devletin mükellef nezdinde vergi bilinci, ahlakı ve uyumunu arttırma çabası, mükelleflerin devlete bağlılık, aidiyet ve güven duygusunu arttırarak seçmen olarak yönetime katılımlarını etkilemektedir. Bu durumda siyasi katılımı arttıracak şekilde vergi ahlakının destekleneceği potansiyel alanlar belirlenebilmektedir (OECD, 2013, s.7-8). Vergi mükellefi profilleri oluşturularak, vatandaşların vergi uygulama ve politikalarına ilişkin tutum ve davranışları analiz edilebilir. Şöyle ki, hangi mükellef grubunun vergi ödeme konusunda daha dirençli olduğu, hangi mükellef grubunun popülist vergi politikaları karşısında kabullenici olduğu tespit edilerek, vergi bilinci ve ahlakına yönelik vergi okuryazarlı̆̆ vergi eğitim modülleri gibi programlar geliştirilebilir. Çalışmadan elde edilen diğer bir bulgu ise vergi yükünün adil dağıldığını düşünen akademisyenlerin, vergi yükünün adil dağılmadığını düşünen ve kararsız olan gruba göre daha fazla vergi ödemesidir. Vatandaşın vergi ödeme kabiliyetinin arttırılabilmesi, gelir ve harcama arası bağlantıların güçlendirilmesi ve açıklığa kavuşturulması için devletin tahsil ettiği vergi gelirlerinin hangi kamusal hizmetlere ne düzeyde aktarıldığı konusunda şeffaflık esası gereği vatandaşların bilgilendirilmesi ve bu bağlamda vatandaşlarda mali hesaplar hakkında devlete karşı hesap sorma yetkisini kullanma hissi oluşumu sağlanabilir. Vergisel gelişmelerin takip türüne bakıldığında ise akademisyenlerin en fazla resmi gazete yoluyla gelişmeleri takip ettikleri görülmektedir.

Demokratik rejimlerde seçim dönemlerinde aktörler, olağan dönemlerde mükellef olan seçmenler, olağan dönemlerde politika uygulayıcıları olan seçilenler, siyasi partiler, bask1 gruplarıdır. Bu süreç doğası gereği, demokratik hak ve özgürlüklerden yararlanma yetkisine sahip vatandaş olarak mükellefin, daha önce uygulanmış ve geleceğe dair vaatte bulunulmuş politikalar karşısında seçmen olarak oy kullanmasına imkân tanımaktadır. Bu noktada, vergilendirme ve demokrasi arasındaki ilişkinin güçlendirilebilmesi, vatandaş ile devlet arasındaki uyum ve güvenin arttırılmasına bağlıdır.

\section{Kaynakça}

Alkan, A. (2009). Vergi bilinci ve vergi uygulamaları karşısında mükellef davranışlarının tespiti: Zonguldak ili örneği (Yayımlanmamış yüksek lisans tezi). T.C. Zonguldak Karaelmas Üniversitesi, Zonguldak.

Alm, J. ve Torgler, B. (2006). Culturel differences and tax morale in United States and in Europe. Journal of Economic Psychology, 27(2), 224-246. doi:10.2139/ssrn.562861.

Aktan, C.C. ve Çoban, H. (2006). Vergileme ekonomisi ve vergileme psikolojisi perspektifinden vergiye karşı tutum ve davranışları belirleyen faktörler, C.C. Aktan, D. Dileyici, I.Y. Vural (Ed), Vergileme ekonomisi ve vergileme psikolojisi içinde (ss.137-157). İstanbul: Seçkin Yayıncilik.

Andersson, P.F. (2018). Democracy, urbanization and tax revenue. Studies in Comparative International Development, 53(1), 111-150. doi:10.1007/s12116-017-9235-0

Arı, E. ve Yıldız, Z. (2016). Bireylerin yaşam memnuniyetini etkileyen faktörlerin sıralı lojistik regresyon analizi ile incelenmesi. Uluslararası Sosyal Araştırmalar Dergisi, 9(42), 1362 1374. doi:10.17719/jisr.20164216245.

Aydoğan, S.D. (2017). Vergi psikolojisinin temelleri ve vergiye karşı davranışları etkileyen faktörlerin değerlendirilmesi. Balkan ve Yakın Doğu Sosyal Bilimler Dergisi, 3, 14-22. 
Baskaran, T. ve Bigsten, A. (2013). Fiscal capacity and the quality of government in Sub-Saharan Africa. World Development, 45, 92-107. doi:10.1016/j.worlddev.2012.09.018

Brant, R. (1990). Assessing proportionality in the proportional odds model for ordinal logistic regression. Biometrics, 46, 1171-1178. doi:10.2307/2532457.

Canbay, T. (2009). Dünyada vergileme anlayışındaki değişim (Antikçağdan günümüze). Bursa: Dora Yayınları.

Cheibub, J.A. (1998). Political regimes and extractive capacity of governments: taxation in democracies and dictatorships. World Politics, 50(03), 349-376. doi:10.1017/S0043887100012843.

Çağan, N. (1980). Demokratik sosyal hukuk devletinde vergilendirme. Ankara Üniversitesi Hukuk Fakültesi Dergisi, 37(1), 129-151. doi:10.1501/Hukfak_0000000814.

Çataloluk, C. (2008). Vergi karşısında mükelleflerin tutum ve davranışları. Selçuk Üniversitesi Sosyal Bilimler Enstitüsü Dergisi, 20, 213-228.

Çevik, S. (2003). Küreselleşen dünyada vergi politikası: vergi politikasında dönüşüm ve küresel sorunlar. Selçuk Üniversitesi Hukuk Fakültesi Dergisi, 11(3-4), 353-369.

Çiçek, U. ve Bitlisli, F. (2017). Vergi eğitiminin üniversite öğrencilerinin vergi bilinci ve farkındalığı üzerindeki etkisi: bir araştırma. Muhasebe ve Vergi Uygulamaları Dergisi, 10(2), 261-278. doi:10.29067/muvu.328734.

Çuhadar, A. (2006). Üniversite ögrretim elemanı ve ögrencilerinin demokrasi anlayışlarının siyasal toplumsallaşma bağlamında cinsiyet, bilim alanı, akademik aşama ve siyasal katılımcılık değişkenleri açısından incelenmesi (Yayımlanmamış yüksek lisans tezi). T.C. Çukurova Üniversitesi, Adana.

Dahl, R. (2017). Demokrasi Üstüne (Kadığlu B.,Çev.). Ankara: Phoenix Yayınevi.

Dahl, R. (2020). Encyclopedia Britannica.<www.britannica.com/topic/democracy>(1.1.2020).

Demir, İ.C. (2013). Seçmen tercihlerinin oluşumunda vergi propagandası: Ampirik bir çalışma. Abant İzet Baysal Üniversitesi Sosyal Bilimler Enstitüsü Dergisi, 13(1), 37-55. doi:10.11616/AbantSbe.305.

Edizdoğan, N. (2008). Kaтu Bütçesi. Bursa: Ekin Kitabevi.

Emeç, H.(2002). Ege bölgesi tüketim harcamaları için sıralı logit tahminleri ve senaryo sonuçları. Dokuz Eylül Üniversitesi Sosyal Bilimler Enstitüsü Dergisi, 4(2), 13-29.

Ercins, G. (2007). Türkiye'de sosyo-ekonomik faktörlere bağlı olarak değişen seçmen davranışı. C.Ü.İktisadi ve İdari Bilimler Dergisi, 8(2), 25-40.

Feld, L.ve Frey, B. (2002). Trust breeds trust: how taxpayers are treated. Economics of Governance, 3(2), 87-99. doi:10.1007/s101010100032.

Frey, B.S. (2017). Proposal for a democracy of the future. Homo Oecon, 34, 1-9. doi:10.1007/s41412-017-0040-9.

Garcia, M.M. ve Haldenwang, C. (2016). Do democracies tax more? Political regime type and taxation. Journal of International Development, 28(4), 485-506. doi:10.1002/jid.3078.

Göztepe, E. (2010). Çoğunlukçu demokrasi anlayışına karşı çoğulcu demokrasi modelleri: Normatif düzenleme olanakları ve bunun sınırlılığı üzerine bazı düşünceler. Катu Hukukçuları Platformu Çoğulcu Demokrasi-Çoğunlukçu Demokrasi İkilemi ve İnsan Hakları Toplantısı içinde (ss. 130-173), Ankara: Türkiye Barolar Birliği Yayınları.

Hançerlioğlu, O. (1999). Ekonomi sözlüğü. İstanbul: Remzi Kitabevi. 
Karyağdı, N. (2015). Vergi satan adamlar. İstanbul: Acar Basım.

Kavra, E. (1989). Montesquieu ve de Tocqueville'e göre demokrasi ve temel güvenceleri. Amme Iddaresi Dergisi, 22(3), 75-83.

Kayan, A. (2000). Verginin tarihsel gelişimi ve sebep olduğu bazı önemli olaylar. Maliye Dergisi, 135, Eylül-Aralık, 80-87.

Muter, N.B., Çelebi, A.K. ve Sakınç, S. (2008). Kamu maliyesi. Manisa: Emek Matbaası.

OECD (2013). What drives tax morale?, www.oecd.org/ctp/tax-global/what-drives-taxmorale.pdf (Erişim tarihi:1.9.2019).

Öz, E. (2004). Tarihi perspektiften Osmanlı'da vergi. Mevzuat Dergisi, 7(84), www.mevzuatdergisi.com/2004/12a/08.htm (Erişim tarihi: 2.9.2019).

Öz, E. ve Güler, A. (2015). Siyasi parti programlarında vergi anlayışları. A. Gerçek ve F. Saraçoğlu(Ed), Prof. Dr. Metin Taş'a armağan içinde (ss.35-64). Ankara: Gazi Kitabevi.

Özözen K.S. (2007). Seçimlerin mekansal analizi (Türkiye ve İstanbul örneğinde seçimlerin coğrafi analizi). Ankara: Gazi Kitabevi.

Prichard, W., Salardi, P. ve Segal, P. (2014). Taxation, non-tax revenue and democracy: New evidence using new cross-country data. ICTD Working Paper, 23. doi:10.1016/j.worlddev.2018.05.014.

Profeta, P., Puglisi, R. ve Scabrosetti, S. (2013). Does democracy affect taxation and government spending? evidence from developing countries. Journal of Comparative Economics, 41, 684718. doi:10.1016/j.jce.2012.10.004.

Sağbaş, İ. ve Saruç, N.T. (2003). Vergi politikalarının seçmenlerin parti tercihi üzerindeki etkisi: ankete dayalı bir çalışma. Vergi Sorunları Dergisi, 130, 130-146.

Sarı, M.M. ve Külekçi, M. (2017). Tarım işletmelerinde örgütlenme durumuna etki eden faktörlerin belirlenmesi: Erzurum ili örneği. I Ĭdır Üniversitesi Fen Bilimleri Enstitüsü Dergisi, 7(1), 319-327. doi:10.21597/jist.2017127444

Schmidth, M.G. (2001). Demokrasi kuramlarına giriş. (Köktaş E., Çev.), Ankara: Vadi Yayınları.

Selim, S. (2012). Avrupa Birliği ülkeleri ve Türkiye'de bireysel yaşam tatmini ve mutluluk düzeylerini etkileyen faktörlerin karşılaş̧ırmalı analizi. Ankara: Gazi Kitabevi.

Sirkeci, O. ve Abdula, M.S. (2015). Ortadoğu uygarlıklarında vergi uygulamaları. International Journal of Social Sciences and Education Research, 1(4), 1239-1252. doi.10.24289/ijsser.279133.

Siverekli Demircan, E. (2004). Türkiye'de vergi politikalarının siyasi analizi siyasi değişimin vergi kayıp ve kaçaklarına etkisi üzerine bir inceleme. 19. Türkiye Maliye Sempozyumu Türkiye'de Vergi Kayıp ve Kaçakları ve Önlenmesi Yolları, Uludağ Üniversitesi, Antalya.

Sultana, T. (2012). The evolution of democracy through the ages: focus on the european experience. Journal of European Studies, 28(1), 27-50.

Şişman, G. (2009). Demokratik ülkelerin anayasalarında yasallık, mali güce göre vergilendirme ve eşitlik ilkelerinin vergi hukuku açısından değerlendirilmesi, Selçuk Üniversitesi Hukuk Fakültesi Dergisi, 17(2), 31-48. doi:10.15337/SUHFD.2017.111

Taşkın, Y. (2010). Vergi psikolojisi ve vergiye karşı mükellef tepkileri, İstanbul Üniversitesi İktisat Fakültesi Maliye Araştırma Merkezi Konferansları 54. 
Teyyare, E. ve Kumbaşl1, E. (2016). Vergi bilinci ve vergi ahlakının gelişmesinde maliye bölümü eğitiminin rolü. T.C.Abant İzzet Baysal Üniversitesi Sosyal Bilimler Dergisi, 16(4), 1-29. doi.10.11616/basbed.vi.455401.

Tezcan, K. (2003). Türk vergi idaresinin tarihsel gelişimi ve bu süreçte geçirdiği aşamaların etkinlik açısından değerlendirilmesi. T.C.Çukurova Üniversitesi Sosyal Bilimler Dergisi, 12(12), 125-146.

Torgler, B. (2003). Tax morale and institutions. CREMA, WP 2003-09, 136.doi:10.2139/ssrn.663686

Turhan, S. (1993). Vergi teorisi ve politikast. İstanbul: Filiz Kitabevi.

Türedi, S. ve Topal, M.H. (2019). Vergilendirme ve demokrasi arasındaki ilişki: Gelişmekte olan ülkeler için panel nedensellik analizi. Eskişehir Osmangazi Üniversitesi İIBF Dergisi, 11(1), 63-86.

Uğurlu, E. (2010). Kesikli Seçim Modelleri, Ders Notları Kitapçık-3, www.researchgate.net/publication/281647356_Kesikli_Secim_Modelleri_Logit_Multinomia 1_Logit_Ordered_Logit_Sirali_Lojit_Lojistik_Model_Marjinal_EtkiOdds_Orani/link/58131a 6d08ae8414914b4ble/download (Erişim tarihi:1.9.2019).

Uygun, O. (2017). Demokrasi tarihsel, siyasal ve felsefi boyutlar. İstanbul: On İki Levha Yayınc1lik.

Yeniçeri, H. (2005). Vergi yükümlerinin vergi karşısındaki tutum ve davranışlarının gelir düzeyine göre karşılaştırılması. Sosyoloji Konferanslart, 31, 279-299.

Yılmaz, S. (2015). Vergileme-demokrasi ilişkisi kapsamında vergiye ve siyasal katılıma ilişkin karşslaştırmalı bir analiz (Yayımlanmamış yüksek lisans tezi). T.C. Bülent Ecevit Üniversitesi, Zonguldak.

Zenginobuz, Ü., Adaman, F., Gökşen, F., Savc1, Ç. ve Tokgöz, E. (2010). Vergi, temsiliyet ve demokrasi ilişsisi üzerine Türkiye'de vatandaşların algıları. İstanbul: Açık Toplum Enstitüsü \& Boğaziçi Üniversitesi Araştırma Fonu.

Ziari, R. ve Rahemi, H. (2013). The relationship between democracy and revenue of budget. International Journal of Management Sciences and Business Research, 2(7), 17-21.

\section{ETİK ve BİLIMSEL İLKELER SORUMLULUK BEYANI}

$\mathrm{Bu}$ çalışmanın tüm hazırlanma süreçlerinde etik kurallara ve bilimsel atıf gösterme ilkelerine riayet edildiğini yazarlar beyan eder. Aksi bir durumun tespiti halinde Afyon Kocatepe Üniversitesi Sosyal Bilimler Dergisi'nin hiçbir sorumluluğu olmayıp, tüm sorumluluk makale yazarlarına aittir. Yazarlar etik kurul izni gerektiren çalışmalarda, izinle ilgili bilgileri (kurul adı, tarih ve sayı no) yöntem bölümünde ve ayrıca burada belirtmişlerdir.

Kurul adı: Manisa Celal Bayar Üniversitesi Rektörlüğü Sosyal ve Beşeri Bilimler Bilimsel Araştırma ve Yayın Etik Kurulu

Tarih : 14.12 .2018

No : 2018/01

Bu çalışma MCBÜ BAPK Birimi tarafından desteklenmiştir, Proje no: 2018-173.

Destekleri için Kurul Başkanı Prof. Dr. Muzaffer TEPEKAYA’ya teşekkür ederiz. 